University of Louisville

ThinkIR: The University of Louisville's Institutional Repository

Electronic Theses and Dissertations

8-2014

\title{
Answering the call : an examination of multicultural competence among academic advising professionals.
}

Tia Noelle Dumas

University of Louisville

Follow this and additional works at: https://ir.library.louisville.edu/etd

Part of the Educational Psychology Commons, and the Student Counseling and Personnel Services Commons

\section{Recommended Citation}

Dumas, Tia Noelle, "Answering the call : an examination of multicultural competence among academic advising professionals." (2014). Electronic Theses and Dissertations. Paper 378.

https://doi.org/10.18297/etd/378

This Doctoral Dissertation is brought to you for free and open access by ThinkIR: The University of Louisville's Institutional Repository. It has been accepted for inclusion in Electronic Theses and Dissertations by an authorized administrator of ThinkIR: The University of Louisville's Institutional Repository. This title appears here courtesy of the author, who has retained all other copyrights. For more information, please contact thinkir@louisville.edu. 


\title{
ANSWERING THE CALL: AN EXAMINATION OF MULTICULTURAL COMPETENCE AMONG ACADEMIC ADVISING PROFESSIONALS
}

\author{
By \\ Tia Noelle Dumas \\ B.A., University of Oregon, 2001 \\ M.A., University of Oregon, 2004

\begin{abstract}
A Dissertation
Submitted to the Faculty of the

College of Education and Human Development of the University of Louisville In Partial Fulfillment of the Requirements

for the Degree of
\end{abstract} \\ Doctor of Philosophy \\ Department of Educational \& Counseling Psychology, Counseling, and \\ College Student Personnel \\ University of Louisville \\ Louisville, Kentucky
}

August 2014 
Copyright 2014 by Tia N. Dumas

All rights reserved 



\title{
ANSWERING THE CALL: AN EXAMINATION OF MULTICULTURAL
} COMPETENCE AMONG ACADEMIC ADVISING PROFESSIONALS

\author{
By
}

Tia Noelle Dumas

B.A., University of Oregon, 2001

M.A., University of Oregon, 2004

A Dissertation Approved on

\begin{abstract}
August 6, 2014
by the following Dissertation Committee:

Dr. Amy Hirschy, Dissertation Chair

Dr. Bridgette Pregliasco

Dr. Shelley Thomas

Dr. Jeff Valentine
\end{abstract}




\section{DEDICATION}

This dissertation is dedicated to my parents, Brenda and Thaddeus (deceased), and to my siblings Tosca, Tara, Thaddeus (deceased), Theo and Troy. I love you with my whole heart. 


\section{ACKNOWLEDGEMENTS}

I would like to thank my dissertation chair, Dr. Amy Hirschy, for her incessant belief in my abilities and my potential, as well as her unparalleled mentoring. Thank you to Dr. Jeff Valentine for introducing me to the world of systematic reviews and for teaching me the power of quantitatively synthesizing studies. My doctoral studies were forever changed as a result of his instruction. I would also like to thank Drs. Bridgette Pregliasco and Shelley Thomas for their feedback, direction, and guidance as members of my dissertation committee.

Thank you to Dr. Nora Scobie, the professional academic advising community, and the student affairs community at the University of Louisville for their participation in my study and their contributions to advancing multicultural competence in the academic advising field. Thank you to the faculty in the College Student Personnel program at the University of Louisville including recently retired professor, Dr. Michael Cuyjet, and Drs. Bridgette Pregliasco and Amy Hirschy for the old and new lessons they shared with me that I will carry onwards for the rest of my career.

I am grateful to my colleagues in the College of Education and Human Development, especially Drs. W. Blake Haselton, Melissa Evans-Andris, and Diane Kyle for their constant encouragement of my professional development as a practitioner, Holmes Scholar, and burgeoning researcher. Thank you to the College of Education and Human Development Diversity Committee, and especially to Drs. Monica Delano and Shelley Thomas. They are champions of social justice. I would also like to acknowledge 
and thank Dr. Ann Larson for teaching me that the quality of strength, lined with bravery and empathy is a powerful combination.

Thank you to my doctoral student peers and graduate student classmates, especially Joy and the graduate assistants and fellows in the ECPY department. I so valued our regular dialogue about all things non-doctoral. Thank you to my friends in California and Oregon, as well as to the members of my extended family in California and Illinois: Daniel and Danielle Gilmore, and Raymond, Isabeau, and Gianna DeGennaro. You inspire me. Finally, I want to extend my deepest appreciation to Kirsten (and family), Dwayne, Kristin (and family), Ben, Angela, Kate, Laura (and family), Julie (and family), and Stefanie (and family) for truly believing in my ability to dare greatly. 


\title{
ABSTRACT \\ ANSWERING THE CALL: AN EXAMINATION OF MULTICULTURAL COMPETENCE AMONG ACADEMIC ADVISING PROFESSIONALS
}

\author{
Tia N. Dumas
}

August 6, 2014

This dissertation examined the relationship between background characteristics and multicultural competence among academic advising professionals at a large, public, urban research institution in the southern United States. It begins with a brief overview of ethical principles in academic advising, focusing on the responsibility academic advisors have to advise all students equitably. The dissertation study is guided by a conceptual framework grounded in student departure theory (Tinto, 1975, 1987, 1993), learning-centered academic advising (Lowenstein, 2005), culturally sustaining pedagogy (Paris, 2012), and multicultural competencies in helping and advising (Pope, Reynolds, \& Mueller, 2004) to argue for an understanding of culturally responsive advising practice as an ethical and social action. The latter part of the dissertation reveals that certain personal and professional attributes affect levels of multicultural competence.

The volunteer, convenience sample consisted of 81 professional academic advisors, and current and recent master's and doctoral students in a counseling and personnel services preparation program. Using an exploratory univariate regression analysis, results from the survey study indicated that race/ethnicity and frequency of participation in multicultural coursework and training are significant predictors of a higher multicultural competence score. The study concludes with implications for both 
research and practice in an era of increasing awareness of the importance of completing a postsecondary degree. 


\section{TABLE OF CONTENTS}

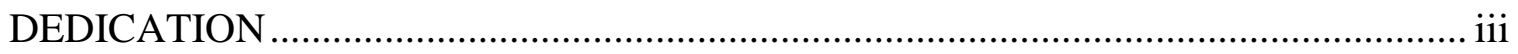

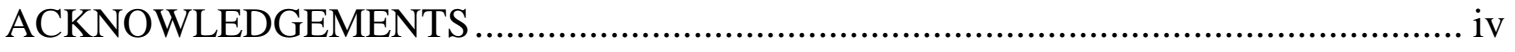

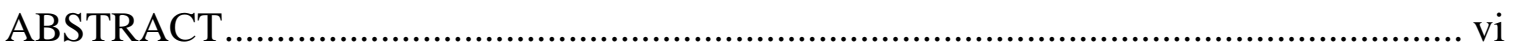

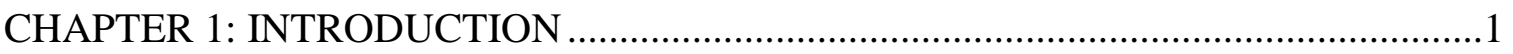

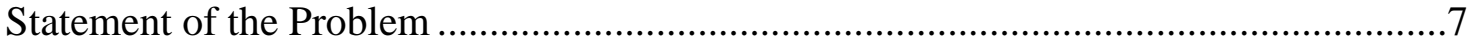

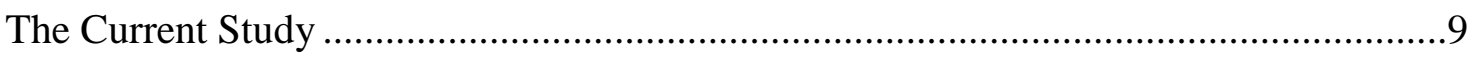

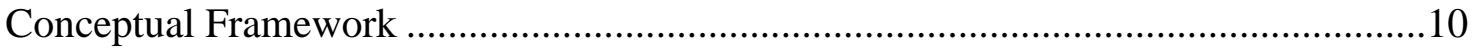

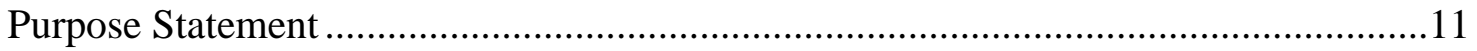

Research Questions and Hypotheses ...............................................................11

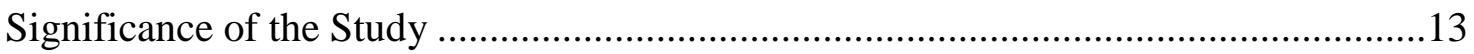

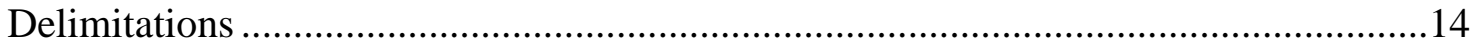

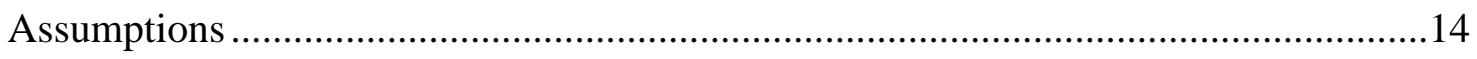

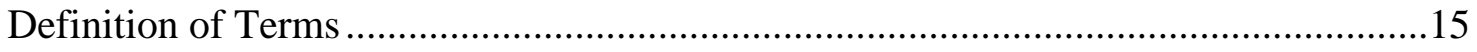

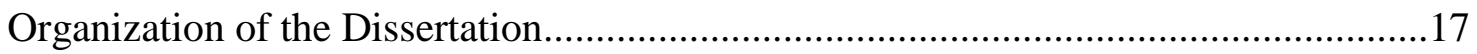

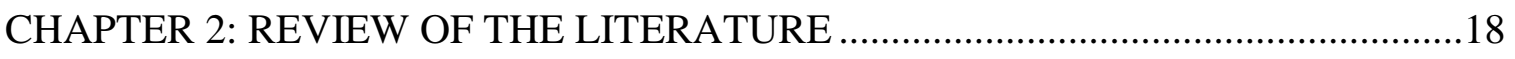

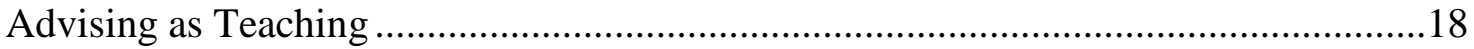

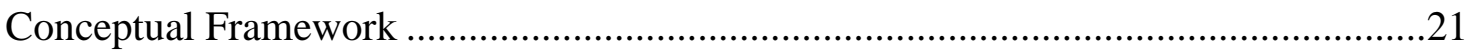

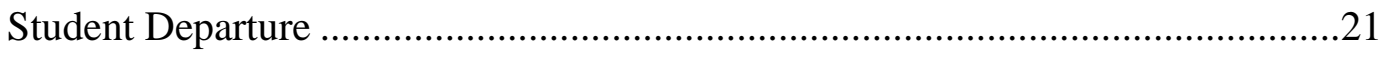

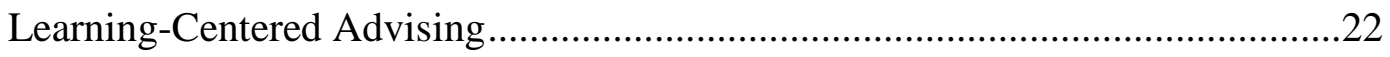

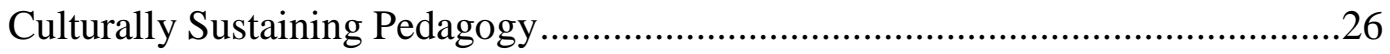

Multicultural Competence in Helping and Advising .......................................27

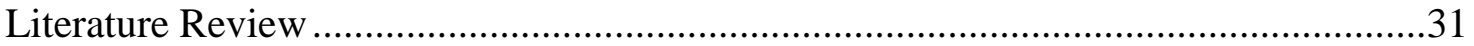

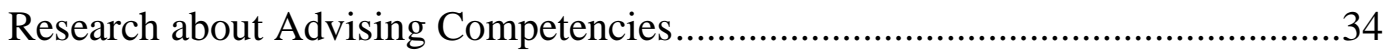

Academic Advising Competencies Summary ..................................................41

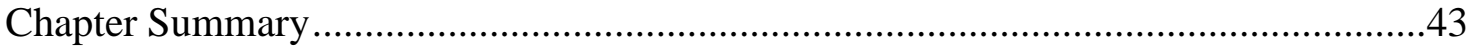

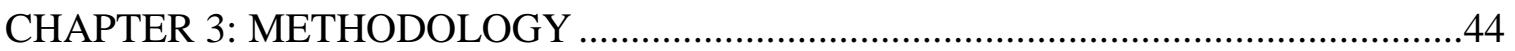




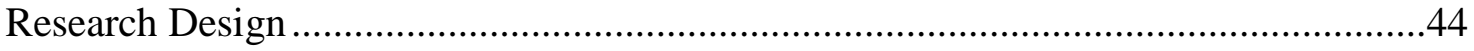

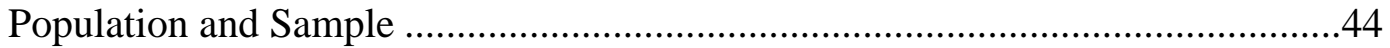

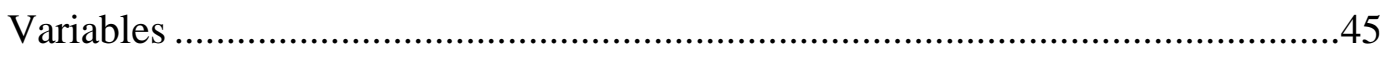

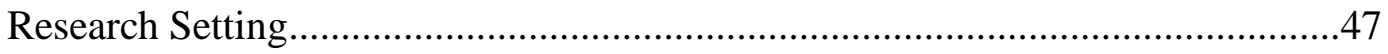

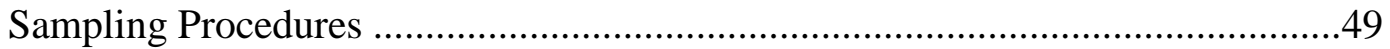

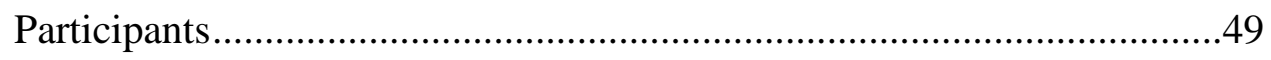

Data Collection Procedures ………………………...........................................50

Multicultural Competence in Student Affairs - Preliminary Form 2 (MCSA-P2) 50

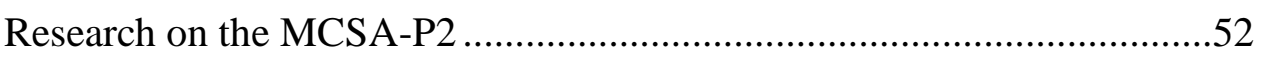

Rationale for the Use of the MCSA-P2 .....................................................53

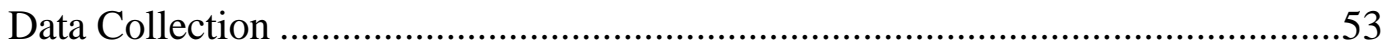

Data Analysis and Research Questions .................................................................53

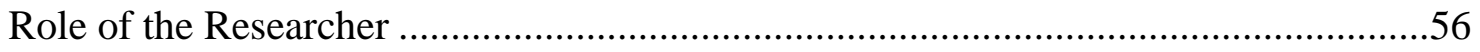

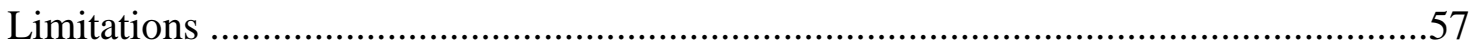

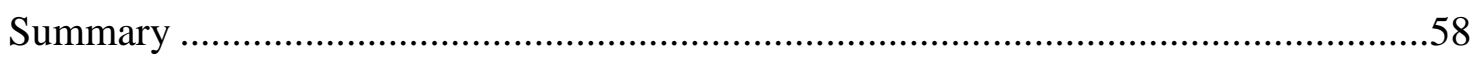

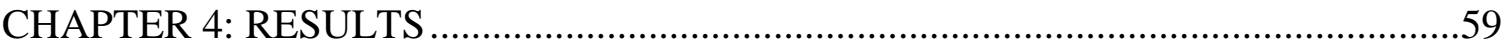

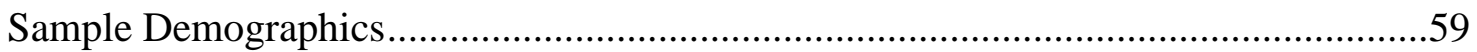

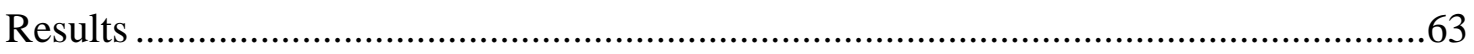

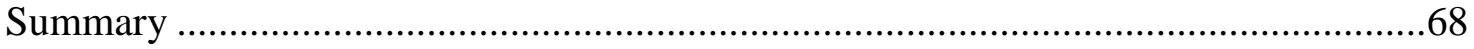

CHAPTER 5: DISCUSSION AND CONCLUSIONS …………………………............

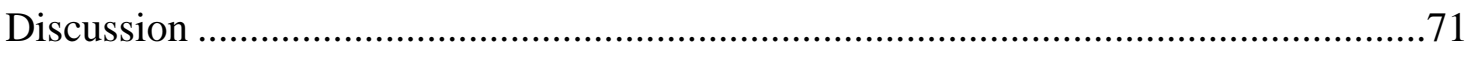

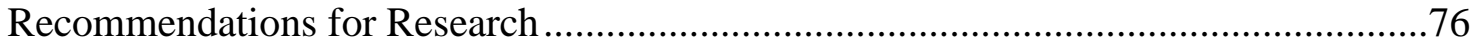

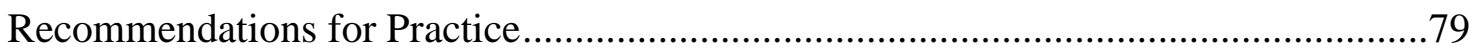

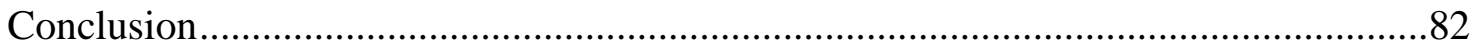

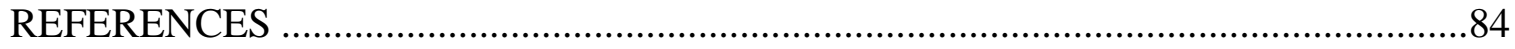

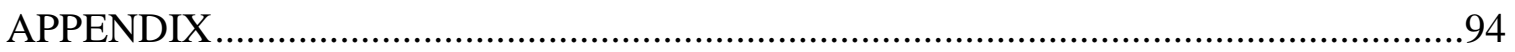

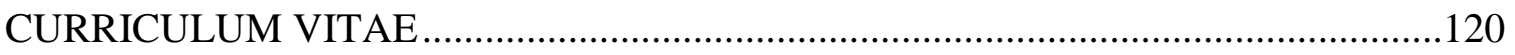




\section{LIST OF TABLES}

1. Ten Central Components of the Advising Relationship............................................103

2. Skills, Knowledge, and Attitudes Required for Advising Students .........................104

3. Characteristics of a Multiculturally Competent Student Affairs Practitioner ...........106

4. Key Categories and Search Terms for ERIC Database .............................................108

5. Key Categories and Search Terms for PsycInfo Database .......................................109

6. Individual Study Characteristics and Mean Effect Sizes for Satisfaction with

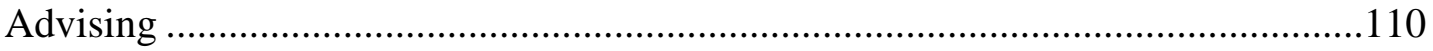

7. Independent Background and Dependent Variables .................................................46

8. Collapsed Independent Variables .............................................................................61

9. General Group Characteristics ............................................................................63

10. Pearson Correlations for Variables Included in the Regression Analysis .................119

11. Multicultural Competence ANOVA Summary Table for Regression ........................65

12. Regression Coefficients and Results of Significance Test ..........................................67

13. Summary of Results ..........................................................................................69

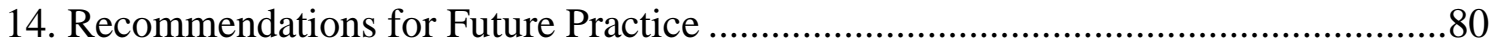




\section{LIST OF FIGURES}

FIGURE PAGE

1. NACADA'S "Statement of Core Values" ..................................................................

2. Conceptual Framework .........................................................................................11

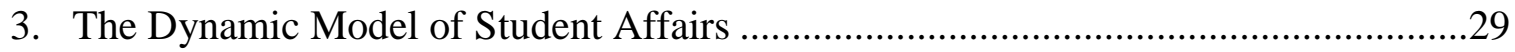

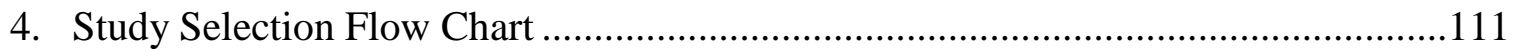




\section{CHAPTER I}

\section{INTRODUCTION}

It can be said that education is the great equalizer. A nation that values educational attainment is a nation that is focused on its ability to compete in a global economy. In his February 24, 2009 address to a Joint Session of Congress, President Barack Obama pledged his commitment to restoring America's leadership in higher education. To achieve this goal by the year 2020, President Obama stated that his administration would address college completion and strengthen the higher education pipeline. Today, college student retention and degree completion continues to be a point of concern for higher education policy makers, researchers, and practitioners. Despite the increases in the number of racial and ethnic minority students attending college over the last fifty years, there are notable disparities among degree completion rates between White students and students of color. In its 2013 publication, the National Center for Education Statistics (NCES) reported that $59.6 \%$ of White students attending a four-year public institution in 2005 completed a degree within six years of starting. This percentage is substantially higher than that of American Indian/Alaska Native students (37.8\%) and Black students (38.6\%), and higher than Hispanic students (48.7\%) and Pacific Islander students (49.5\%). Past studies have shown a number of reasons for the group differences in degree completion rates including prior academic preparation, family background, employment status, socioeconomic status, college financing, and 
student involvement (Cabrera et al., 1999; Fischer, 2007; Tinto, 1993). The breakdown of racial and ethnic minority students to obtain a college degree may have negative effects on both the individual and American society. Primary individual disadvantages include lower levels of employment, lower earnings, and poorer job satisfaction (Jones, 2013). American society is disadvantaged by higher rates of unemployment, higher rates of incarceration, lower local, state, and federal tax revenues, and lower levels of academic preparation among future generations (Carter, 2006; Museus \& Ravello, 2010; Settle, 2011). Combined, these effects thwart America's chances of being a global leader in higher education and, perhaps more importantly, a nation committed to equitable access to opportunity for all.

The growing awareness of the importance of completing a postsecondary degree has prompted campus educators to examine their roles in the preparation of students for life, work, and civic participation in an increasingly complex world. One such group of campus educators -academic advisors- considers how the nature of advising practices and relationships with students fosters student learning and development, retention, and degree completion. For instance, based on a review of the NACADA Journal subject index, the premier peer-reviewed academic journal for academic advising, the number of publications related to student learning and development, retention, and degree completion has grown over the last 30 years. Between 1981 and 1995 there were a total of 27 articles published under the subject descriptors attrition and retention. Between 1996 and 2010 there were a total of 116 articles published under these same, or similar, subject descriptors, an increase of approximately 330\%, underscoring the growing awareness of the importance of these issues to academic advising and academic advisors. 
Given the attention paid to the role of academic advising in postsecondary degree completion, it would follow that the academic advising field would be saturated with empirical studies investigating effective advising practices, especially practices that address the disparities in degree completion between White students and students of color. However, after a review of the same NACADA Journal subject descriptors and article titles, there were a total of 30 articles that addressed issues specifically related to students of color. A leading factor described in the advising literature that has contributed to the scarcity of empirical research in this area is that academic advising emerged from student personnel services and was distanced from the curriculum, faculty, and research, therefore implying a binary relationship between practitioner and researcher (Kuhn, 2008; Rhatigan, 2009). Additional contributing factors may include: (1) The assumption that advising students holistically also means advising all students equally or the same; (2) The assumption that academic advisors do not need to understand cultural nuances of an ever-changing population of students to assist students with course scheduling and registration; and (3) The assumption that because academic advisors are inherently good, they will provide equitable and fair advising support to all students. Not only do these assumptions minimize the role of academic advisors in the success of students of color, they also challenge ethical foundations of academic advising, and the notion that American society is both diverse and complex.

From its beginnings as one form of counseling within student personnel services, academic advising emerged as an independent field within American higher education in the early 1970s (Kuhn, 2008). Academic advising can be described as the situations in which an institutional representative gives insight or direction to a college student about 
an academic, social, or personal matter (Kuh, 2008). Academic advising is delivered in several different ways based on institutional classification (e.g., research institution, liberal arts institution, private institution, etc.), type of advising system (e.g., centralized, de-centralized, shared, etc.), and type of institutional representative (e.g., faculty advisors, professional advisors, counselors, and other staff). Generally speaking, most college students will interact with a faculty advisor, a professional advisor, or a combination of the two at some point during their college experience. Faculty advisors have a primary responsibility to both determine the mission of the institution and to teach the academic curriculum. This responsibility makes faculty advisors central to helping students understand the overall purpose of their academic program and what they are learning (McGillin, as cited in Hemwall, 2008). Unlike faculty advisors, professional advisors have been hired to devote the majority of their workdays to meeting directly with students to address academic curriculum requirements, institutional policies and procedures, and personal student development and success issues (Self, 2008). Given the importance of both faculty advisors and professional advisors to student learning, personal development, and success, it seems reasonable to expect these professionals to have a general awareness, at least, of the significant roles they play in degree completion for students of color.

The academic advising community has recently begun to reveal the characteristics of academic advising skills that promote success among college students of color (Museus \& Ravello, 2010). In their study about how academic advisors contribute to the success of students of color at institutions with high racial and ethnic minority retention and degree completion rates, Museus and Ravello (2010) reported three themes that emerged 
from their findings: (1) advisors humanized the practice of academic advising, (2)

advisors provided holistic advising, and (3) advisors were proactive. One framework that is particularly useful for understanding the concept of humanizing is Rendón's (1994) theory of validation. In the theory of validation, Rendón (1994) argued that acknowledging, valuing, and confirming a student's prior knowledge and beliefs would ultimately help the student transition into a campus and to also be successful there. Rather than encouraging students to disassociate from their pre-college memberships and cultural affiliations, Rendón (1994) held that faculty and staff should engage in a process to validate students and their unique, diverse characteristics.

Museus and Ravello (2010) also highlighted the impact of academic advisors who made efforts to advise the whole student. This included being aware that a minority students' issues are usually multidimensional (e.g., academic, personal, and financial), and ensuring that minority students received the support they needed, regardless of the nature of their issues. Finally, study participants underscored the importance of proactive academic advisors, who made both informal and systematic efforts to connect students of color with the resources they needed to succeed.

While their study illuminated how academic advising contributes to the success of students of color, Museus and Ravello (2010) also quietly asked the academic advising community "What is the right thing to do?" when advising students of color? To help structure responses to this question, Lowenstein (2008) provided a series of ethical principles that refer directly to advising grounded in basic ethical ideals. One foundational ideal that is most relevant to the ways academic advisors can support students of color, is the ideal justice. Lowenstein (2008) described justice as treating: 
...all individuals fairly or equitably, granting no one any special rights or privileges that are not open to all. "Equitably" does not have to mean "the same"; it just means that differences must not create inequalities, and should have a defensible basis. (p.

Lowenstein's (2008) ethical principles are reinforced in The National Academic Advising Association's (NACADA) "Statement of Core Values". NACADA is recognized as a global professional association for academic advising and its purpose it to "promote the quality of Academic Advising in institutions of higher education, and to this end, it is dedicated to the support and professional growth of academic advising and advisors (http://www.nacada.ksu.edu/About-Us/History.aspx)." Although NACADA does not provide a code of ethics for its membership, in 1993 it drafted and printed The Core Values for Advising. In 2005 The Core Values for Advising were updated and resulted in a "Statement of Core Values" to guide professional practice and remind advisors of their responsibilities to students, colleagues, institutions, society and themselves (NACADA, 2005). The "Statement of Core Values" consists of three parts including the Introduction, the Declaration, and the Exposition. Figure 1 provides an illustration of NACADA's "Statement of Core Values." 


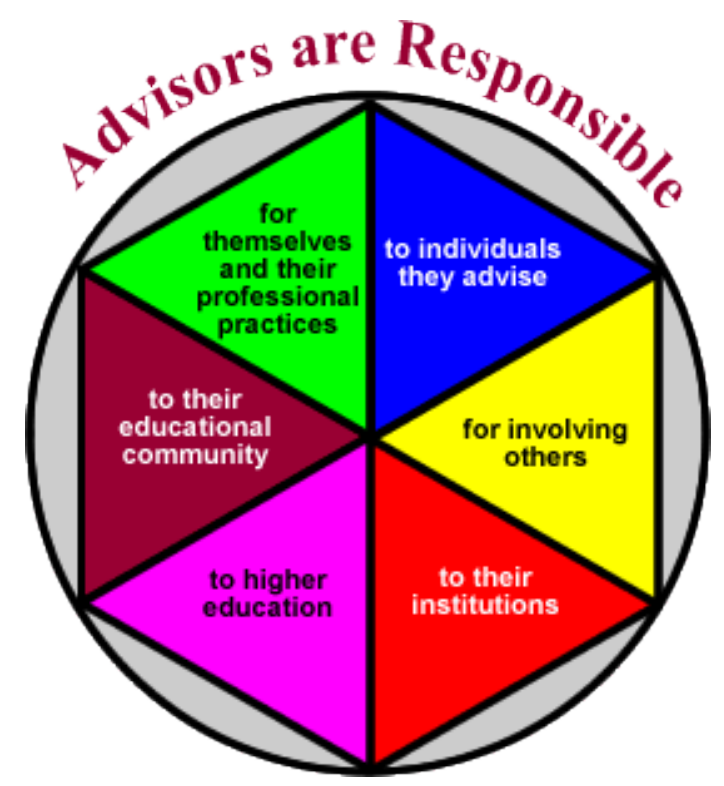

Figure 1. NACADA Statement of Core Values. Reprinted with permission from NACADA Clearinghouse of Academic Advising Resources. Copyright 2014 by the National Academic Advising Association (NACADA) www.nacada.ksu.edu.

\section{Statement of the Problem}

According to Kuh (2008), the "quality of academic advising is the single most powerful predictor of satisfaction with the campus environment for students at four-year schools" (p. 73). Satisfaction with advising is significant because it is an indicator of how well the student's expectations about the college experience are being met in reality. Students who indicate having a positive experience with advising are more likely to obtain information about academic support options, engage with the campus environment, and interact with faculty (Kuh, 2008; NSSE, 2013). Moreover, institutions that provide students with extended advising and counseling services are more likely to increase student retention (Tinto, 1993). And yet, in its 2013 annual publication about the student experience with academic advising, including frequency of contact, information provided, and accessibility, National Survey of Student Engagement (NSSE) results indicated that one in ten students never met with an advisor. Only about $40 \%$ of 
students identified an academic advisor as their primary source of advice regarding academic plans, and less than one-third of first-year students, and eighteen percent of seniors identified friends or family as their primary source of academic advice (NSSE, 2013). Another $18 \%$ of seniors sought advice from faculty who were not formally assigned as an advisor (NSSE, 2013). Given the importance of academic advising in the persistence and degree completion of students, it is alarming that there is such little contact with academic advisors. Determining the factors that are contributing to this disconnect with students is imperative.

It is evident that academic advisors have an ethical responsibility to advise all students equitably. However, it is unclear exactly how academic advisors can deliver equitable advising services to populations of students, such as students of color, whose educational histories and foundations are marred with legal and social injustices. An initial step academic advisors can take to deliver equitable advising services to students of color is to reshape how and why advisors give insight and direction. For instance, in addition to sharing or imparting knowledge about an academic, social, or personal matter with students of color, I argue that academic advisors also translate their knowledge in ways that students of color can interpret and apply to their educational experiences. And instead of loosely defining success as personal development and academic achievement, I posit that academic advisors more accurately define success as degree completion that fosters the creation of, and not simply participation in, a more just society.

So, what does an academic advisor need to know and need to do to become a cultural translator for social justice? Past literature recommends several different sets of skills and competencies an academic advisor should be familiar with and use in advising 
practice, such as planning and organization skills, demonstrated care for students, being approachable, and being available (Bloom et al., 2007; Fiddler \& Alicea, 1996; Fox, 2008; Harding, 2008; Harrison, 2009). However, too often these sets of skills do not fully reflect the proficiencies and level of competency necessary for working with students of color because the studies (a) did not include or report on samples of students of color, (b) did not include or report on samples of advisors of color, and/or (c) were restricted to geographic regions of the United States with few populations of color.

\section{The Current Study}

There is an urgent and momentous need to examine the attitudes, the sets of skills, and the knowledge academic advisors of all backgrounds currently have in relation to supporting students of color. Research contends that advisors' communication styles, beliefs, values, worldviews, and perceptions about students of color are some of the characteristics needing to be better understood (Brown \& Rivas, 1993; Castellanos et al., 2007; Clark \& Kalionzes, 2008; Coll, 2009; Cuyjet et al., 2011; Harding, 2008; King \& Howard-Hamilton, 2003). It is also imperative to explore the degree to which an academic advisor's personal and professional background affects those characteristics (Harding, 2008; Porter, 2011). Harding (2008) claimed that when advising a very diverse population of students, the most important strategy is to treat the individual within the cultural context. He conjectured that this involves building partnerships with various campus resources, understanding one's own cultural biases and level of cultural competency, and fostering relationships with students. This study aims to better inform the academic advising field about the proficiencies essential to providing equitable and ethical advising to students of color. 


\section{Conceptual Framework}

No single model was found to describe the factors that impact fair and just advising practices that promote degree completion among students of color. Thus, I discuss theoretical perspectives used to conceptualize college student retention, academic advising as teaching, and multicultural competence in helping and advising. I borrow from student departure theory (Tinto, 1975, 1987, 1993), learning-centered academic advising (Lowenstein, 2005), culturally sustaining pedagogy (Paris, 2012), and multicultural competencies in helping and advising (Pope, Reynolds, \& Mueller, 2004). These theories frame the current study due to their ability to connect the decisions and actions of students of color with the institutional efforts necessary to address the disparity of degree completion between White students and students of color. Tinto's theory of student departure is discussed first to set the stage for how students of color academically and socially engage with the campus community. Next, learning-centered advising (Lowenstein, 2005) is presented to emphasize how academic advisors can facilitate student learning and their preparation for global citizenship. Then, culturally sustaining pedagogy (Paris, 2012) is introduced to address the cultural limitations found in both of the student departure and learning-centered advising theories. Finally, Pope, Reynolds, and Mueller's (2004) multicultural competencies in helping and advising is integrated to demonstrate how academic advisors can operationalize theory in their daily practice. Figure 2 illustrates the conceptual model that guides this study. 


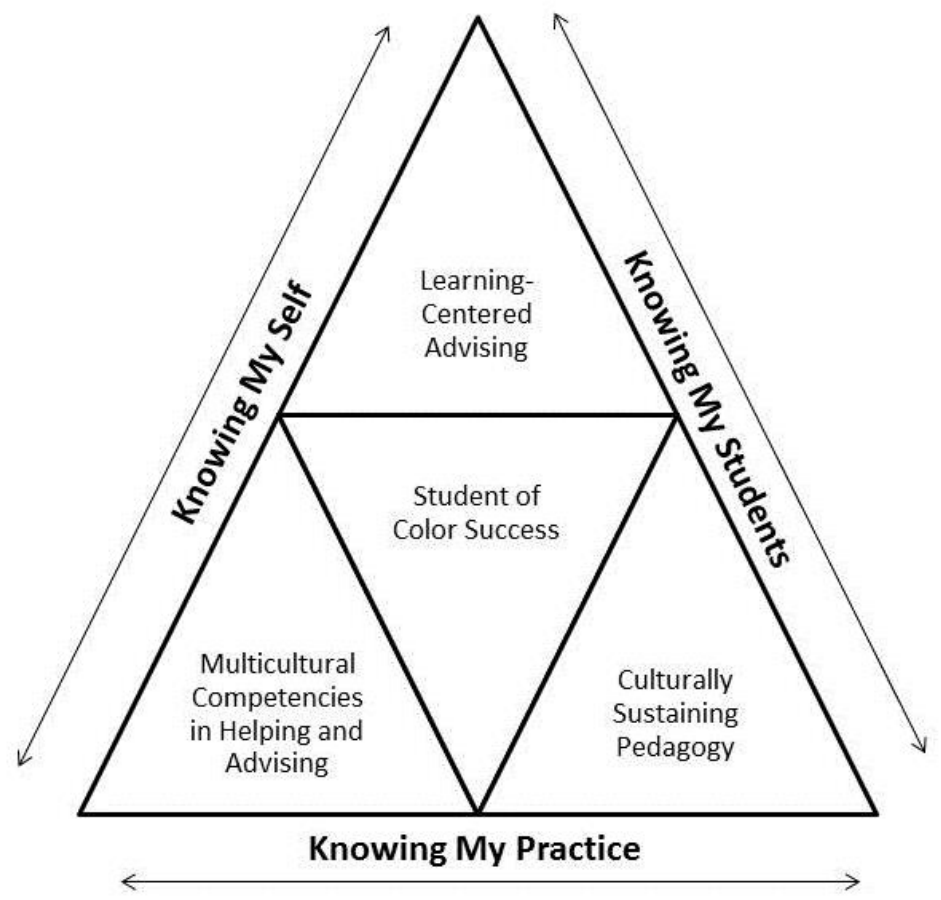

Figure 2. Conceptual Framework.

\section{Purpose Statement}

The purposes of this study were to identify and examine the relationships between personal and professional background characteristics and multicultural competence among participants. Multicultural competence is defined as "the awareness, knowledge, and skills needed to work with others who are culturally different from self in meaningful, relevant, and productive ways” (Pope, Reynolds, \& Mueller, 2004, p. 13).

\section{Research Questions and Hypotheses}

This research study examined the relationship between key variables, participant's personal and professional attributes and multicultural competence, in the context of effective advising skills. Four research questions and their corresponding hypotheses were addressed in this study. Further information about the methodology used to test these hypotheses is discussed in Chapter 3. 
RQ 1: Are there relationships between personal background characteristics (e.g., gender identity, race/ethnicity, engagement with populations different from one's own racial identity, highest degree completed by a parent/guardian, and sexual orientation) and multicultural competence score?

H1: The personal background characteristics racelethnicity, highest degree completed by a parent/guardian, and sexual orientation will have significantly positive, stronger correlations with multicultural competence score than other personal background characteristics.

RQ 2: Are there relationships between professional background characteristics (e.g., years of professional experience, academic degree level, and frequency of participation in multicultural coursework and training) and multicultural competence score?

$\mathrm{H} 2$ : The characteristic frequency of participation in multicultural coursework and training will have a significantly positive, stronger correlation with multicultural competence score than other professional background characteristics.

RQ 3: Which background characteristics best predict multicultural competence score among participants?

H3: The background characteristics that will significantly predict multicultural competence score will be: sexual orientation, racelethnicity, and highest degree completed by a parent/guardian, along with engagement with populations racially different from one's self, and frequency of participation in multicultural coursework and training. 
RQ 4: What are the combined effects of engagement with populations different from one's own racial identity and frequency of participation in multicultural coursework and training on multicultural competence score?

H4: There will be a significant interaction effect of engagement with populations different from one's own racial identity and frequency of participation in multicultural coursework and training on multicultural competence score.

\section{Significance of the Study}

The call to postsecondary education to generate a more educated, socially just American citizenry has been made by President Obama. Increasing degree completion rates for all students, and especially students of color, is cardinal to answering this call. Academic advisors have an ethical responsibility to contribute to the dismantling of inequalities and play a central role in the academic, personal, and social success of students of color (Grites, Gordon, \& Habley, 2008). The issue that it is unclear to academic advisors is the degree to which personal and professional background characteristics affect multicultural competence.

In a discussion about future directions for diversity research in student affairs, Pope, Mueller, and Reynolds (2009) asserted that multicultural research that is participant centered and practitioner-oriented will have the most impact on student affairs practice. They added, "This requires not only expanding the research methodologies and approaches used but engaging student affairs practitioners to actively participate in systematic inquiry to understand and extend the value of diversity on campuses" (p. 654). Through an examination of the background characteristics that are linked to multicultural competence, academic advisors, faculty, and students in counseling and personnel 
services can acknowledge and develop attributes that support efficacious work in academic advising. Perhaps more importantly, this study can guide professional practice and inform academic advisors of their ethical responsibilities to themselves, students, colleagues, their institutions, and society.

\section{Delimitations}

This study was conducted during the summer 2014 semester of an academic school year. The location of the study was at a large, predominantly White, public, urban research institution in the southern United States. Those surveyed in this study consisted of 81 professional academic advisors, and/or current and recent master's and doctoral students in a counseling and personnel services preparation program. The results of this study could be generalized to professional academic advisors and current and recent master's and doctoral students in a counseling and personnel services program at a predominantly White, public, urban research institution.

\section{Assumptions}

This study was based on the following assumptions. First, the sample studied was representative of the total population of professional advisors employed at this institution. Second, the sample studied was also representative of the total population of master's and doctoral students in a counseling and personnel services preparation program at this institution. Third, the participants surveyed in this study answered all of the survey questions openly and honestly. Finally, that a large, predominantly White institution in an urban setting would provide the possibility for more interaction with people of color than a large predominantly White institution in a rural setting based on the racial/ethnic demographics in each geographic region (USDA, 2013). 


\section{Definition of Terms}

Academic Advising: "situations in which an institutional representative gives insight or direction to a college student about an academic, social, or personal matter" (Kuhn, 2008, p. 3).

Academic Advisor: a professional advisor employed to "devote the majority of their workday to meeting directly with students to address academic curriculum requirements, college policies and procedures, and general student development and success issues. Professional advisors seek to teach their advisees the skills and knowledge that will ultimately result in the students' succeeding in their academic and personal goals" (Self, 2008, p. 269).

Advisee: an undergraduate, master's, or doctoral student receiving insight or direction from an academic advisor or faculty advisor.

Advising Center Director: a professional advisor or individual hired to direct student service activities such as admission, advising, retention, and graduation of undergraduate programs.

Advising Skills: behaviors that allow academic advising professionals to effectively apply values, assumptions, and content knowledge in advising interactions across cultural groups.

Culturally Sustaining Pedagogy: “...requires that our pedagogies be more responsive of or relevant to the cultural experiences and practices of young people - it requires that they support young people in sustaining the cultural and linguistic competence of their communities while simultaneously offering access to dominant cultural competence" (Paris, 2012, p. 95). 
Faculty Advisor: an individual whose primary responsibility at the institution is to teach or conduct research. Faculty advising "may focus on the academic curriculum or career opportunities related to a specific major or area of study, along with time and attention to addressing student development and success issues" (Self, 2008, p. 267).

Multicultural Competence: "the awareness, knowledge, and skills needed to work with others who are culturally different from self in meaningful, relevant, and productive ways" (Pope, Reynolds, \& Mueller, 2004, p.13).

Retention: staying in school until completion of a degree; often used interchangeably with "persistence" (Hagedorn, 2005).

Socially Marginalized Group: refers to individuals who identify with the lesbian, gay, bisexual, queer, or questioning community, and/or religious minorities (Mueller \& Pope, 2001).

Student of Color: used to refer to students who identify with the socially constructed American Indian or Alaska Native, Asian, Native Hawaiian or Pacific Islander, Black or African American, Hispanic or Latino/a, and Two or More Races racial categories (http://nces.ed.gov/programs/coe/glossary.asp). The terms "racial and ethnic minority," "minority," and "student(s) of color" may also be used interchangeably with this term. Student Success: "represents academic achievement, engagement in educationally purposeful activities, satisfaction, acquisition of desired knowledge, skills, and competencies, persistence, and attainment of educational objectives" (Kuh, 2008).

Underrepresented Groups: includes groups that are underrepresented in postsecondary education including individuals who are "first-generation college students, from minority racial or ethnic groups, from families with low incomes, from nontraditional ages and 
backgrounds, or who have a combination of characteristics that signify

underrepresentation" (Jones, 2013, p. 5).

\section{Organization of the Dissertation}

The remainder of this study is organized into four chapters, appendices, and a

reference section. Chapter 2 presents a critical synthesis of empirical literature about the concept of academic advising and multicultural competence in helping and advising. Chapter 3 describes the research design and methodology in this study. An analysis of the data and a discussion of the findings are presented in Chapter 4. Finally, Chapter 5 contains the summary, conclusions, and implications of the study. 


\section{CHAPTER II}

\section{REVIEW OF THE LITERATURE}

This dissertation study examined the relationship between academic advisors' personal and professional background characteristics and multicultural competence score. This chapter situates the study in the context of previous research about advising skills and multicultural competence in academic advising, and is divided into three sections: (1) a brief overview of the concept of "advising as teaching", (2) the conceptual framework for the study, and (3) a review of the literature. I conclude by synthesizing how previous studies are related to each other and to this dissertation study.

\section{Advising As Teaching}

The concept of "advising as teaching" (p. 12) was first introduced to the academic advising field in a seminal article by Crookston (1972). In the mid-1960s, a developmental definition of mental health set the foundation for utilizing tasks for personal growth. Crookston (1972) claimed that since these developmental tasks were centered on helping an individual live effectively in a rapidly changing society, it was important that an academic advisor also recognize the need to change oneself if one expected to stay engaged with students in a changing world. Crookston (1972) argued that developmental advising is not only concerned with the vocational decisions a student makes, but also with the rationale processes, behavioral awareness, and decision-making skills. He based this claim on two basic assumptions from student development theory: First, that a student's career goals should be situated within the development of a life 
plan, instead of the tendency to develop a life around one's professional goals; and second, that teaching includes any experience in the learning environment in which a student and teacher interact that contributes to individual or group growth that can be measured. Within that context, the student shares equal responsibility with the teacher or advisor in the advising relationship for the quality of the learning experience (Crookston, 1972).

Crookston (1972) viewed the relationship between student and advisor as critical to identifying aspects of a developmental relationship from those that are not. Toward that end, he offered two contrasting behavioral styles of connecting to a student: prescriptive and developmental. A prescriptive relationship is one based on authority and results when the advisor diagnoses the student's issues or concerns and prescribes a remedy. In this context, the assumption is that the advisor "teaches" and the student "learns." A developmental relationship involves the advisor and the student engaging collaboratively in a series of tasks to address the student's concerns, resulting in varying degrees of learning by both parties (Crookston, 1972; Winston \& Sandor, 1984). Table 1, adapted from Crookston (1972), compares 10 central components of the relationship between the student and advisor differentiating between a prescriptive and developmental advising approach (see Appendix B).

O’Banion (1972) shared Crookston's (1972) viewpoint that a student's professional goals should be generated in the context of the student's life plan, and proposed an advising model based on a sequence of five dimensions: "(1) exploration of life goals, (2) exploration of vocational goals, (3) program choice, (4) course choice, and (5) scheduling courses" (p. 62). O’Banion (1972) suggested that students should be 
responsible for making decisions in the advising relationship and that advisors are responsible for providing a climate of freedom in which students can make such decisions. To better understand these dimensions, or steps, O’Banion (1972) offered the skills, attitudes, and knowledge required by the advisor who will assist students in each of the five dimensions of the advising process. Table 2 reflects these proficiencies (see Appendix B).

While Crookston and O'Banion's methods are the cornerstones of approaches applicable to academic advising, a number of different approaches have been identified since the turn of the century. Currently, there is no grand unified theory of advising. Hagen and Jordan (2008) held that a universal perspective is neither possible nor desirable. Multiple theories can meet the diverse needs of students, and Hagen and Jordan (2008) suggested that advisors should be familiar with a broad base of theories and metatheories to incorporate into their daily practice, such as analogic theories and normative theories. Analogic theories borrow concepts and ideas from other fields and apply them to advising. Normative theories build an ideal toward which advising should lean and can be broken into two groups: traditional normative approaches, such as developmental advising and theories of student development, and newer normative approaches or theories that have emerged since 1999 and serve as alternatives to developmental advising. Some of these alternatives include, Hemwall and Trachte's (2000) "learning at the core" and Melander's (2005) "educative advising." Hagen and Jordan (2008) recommended that academic advisors draw from a variety of theoretical perspectives because they come to advising from many different disciplines and not from 
any one field. The next section will focus on an integrated framework that can shape and inform theory-to-practice in academic advising.

\section{Conceptual Framework}

To properly frame this study, and to describe efficacious advising practices when working with students of color, I ground this study in Tinto's $(1975,1987,1993)$ theory of student departure, learning-centered advising (Lowenstein, 2005), culturally sustaining pedagogy (Paris, 2012), and multicultural competencies in helping and advising (Pope, Reynolds, \& Mueller, 2004).

\section{Student Departure}

Building on the work of Spady (1970), Tinto proposed a three-stage model of student departure based upon the sociological conception of suicide (Durkheim, 1951) and research from the field of social anthropology, specifically referring to the work of Van Gennep (1960) and his study of the rites of membership in tribal societies.

According to Tinto $(1987,1993)$, the three stages of withdrawal from institutions of higher education included: separation, transition, and incorporation. Tinto (1993) drew connections between the concepts of suicide, rites of passage, and college student dropout and persistence, and conceptualized retention as a process of interactions between the student and the institution. For Tinto (1975), academic interactions and normative congruence lead to academic integration. When these characteristics are not in sync, students experience isolation, and are more likely to withdraw from college.

Despite its broad usefulness as a framework, practitioners must be careful not to oversimplify what is a very complex situation that is not experienced in the same way by every student (Cuyjet, 2011; Tinto, 1987). Over the years, researchers have been critical 
of Tinto's model, carefully examining the assumptions and applicability of the model to the diversity of students enrolled in institutions of higher education. For example, issues unique to students of color were not fully examined in Tinto's original work. Therefore, some scholars assert that the social-academic integration model may not be the most appropriate model for explaining student departure for students of color or those from other underrepresented or socially marginalized groups such as lesbian, gay, bisexual, transgender, and queer (LGBTQ) students, or non-traditional students (Cuyjet, 2011; Guiffrida, 2006; Rendón, Jalomo, \& Nora, 2000). For instance, Rendón, Jalomo, and Nora (2000) provided a critical analysis of Tinto's theory with a specific focus on the separation and transition stages. They argued that scholars investigating how minority students make the transition to college should be familiar with biculturalism and dual socialization, which challenge the assumption of separation (Rendón et al., 2000). To elaborate, students of color are not likely to give up their pre-college memberships and affiliations with their cultural groups in order to find membership in a new college world. Navigating two worlds, one of which may be entirely different from home, however, is not the sole responsibility of the student; instead, it requires both individual and institutional effort. Rendón et al. (2000) posited this dual responsibility as the reason that the use of cultural programs and role models are so important to provide information and support that can help students traverse unfamiliar college customs and culture.

\section{Learning-Centered Advising}

Not all students have the same needs, nor do they benefit from the same advising practices. One approach with potential merit in the success of students of color is learning-centered academic advising. This newer normative approach focuses on 
advising in the context of the learning process and it has been instrumental in developing the guiding metaphor of the National Academic Advising Association (NACADA) "advising is teaching." Hemwall and Trachte (1999) offered the term praxis, used in educational theory and associated with the work of Pablo Freire (1970), to more accurately describe the connection between academic advising and the main mission of higher education as they saw it: student learning and the preparation of global citizenship. Hemwall and Trachte (1999) argued that "the model of developmental academic advising should be abandoned and replaced by alternative theoretical traditions" (p. 5) because the model separates the personal development of the student from the central educational mission of higher education. If praxis is an analogue for academic advising, Hemwall and Trachte (1999) held that it is through critical self-reflection that academic advisors can help students transform the world, arguing that "a person must be able to understand and analyze the beliefs, norms, assumptions, and practices that give meaning to his or her world" (p. 8) in order to change it. They conjectured that it is the emphasis on change, or learning rather than personal development, "that makes clear that self-transformation (making meaning of the world to transform it) not self-actualization (primarily identifying individual self-development) is the most important goal of praxis" (Hemwall \& Trachte, 1999, p. 9).

Hemwall and Trachte (2005) built on their earlier work by offering ten organizing principles to answer two questions raised by a focus on learning; (a) what should the student learn through academic advising (curriculum)? and (b) how might this learning occur (pedagogy)? Of the ten organizing principles, three are used to define the advising curriculum. The first organizing principle for the advising curriculum is that academic 
advising should facilitate student learning about the mission of the institution. Second, academic advising should facilitate critical thinking skills. Third, academic advising should facilitate critical self-reflection about the ways students can achieve their goals aligned with those in the institution's mission statement. The "curriculum" of advisingas-teaching is to teach according to the mission of the institution that developed the curriculum.

As to the pedagogy of advising-as-teaching, Hemwall and Trachte (2005) offered the following seven principles:

1. Students are responsible for actively constructing their understanding of the institutional mission, including concepts such as becoming a critical thinker.

2. Advisors must integrate knowledge of different learning styles into their advising practice.

3. Advisors must consider how the social context affects the student's understanding of the meaning of education.

4. The student's background and preexisting knowledge affect his/her possibilities for learning.

5. Students must be allowed an equal part in the dialogue to express, justify, and discuss their goals.

6. Academic advisors must be engaged in the learning process, and guide the student to a more sophisticated understanding of liberal learning.

7. Academic advisors must foster moments of disequilibrium and guide students through these moments (adapted from Hemwall \& Trachte, 2005, pp. 77-81). 
Lowenstein (2005) supported Hemwall and Trachte's (1999) notion that the most compelling model of teaching and advising is the learning-centered paradigm. Introducing the concept of the logic of the curriculum to the advising-as-teaching conversation, Lowenstein (2005) argued that an excellent professional advisor helps a student make sense of his/her curriculum. He posited that if advising is teaching and the participation with advising is learning, then it makes sense to conduct advising practice in ways similar to faculty and classroom teaching. Lowenstein (2005) demonstrated how the learning-centered paradigm elevates the professional academic advisor's role on campus to educational partner with faculty.

Although Hemwall and Trachte $(1999,2005)$ and Lowenstein (2005) offered ideas about how professional academic advisors can align their advising practice with the curriculum of their institutions, there is one significant cultural limitation to their assertions. These scholars focused more on guiding principles and less on the ways professional academic advisors can teach students about how their cultural identities can inform their learning and the learning of those around them. To that end, if the mission of an institution, in part, espouses the preparation of students for a more diverse, complex, and global world, then in what ways can professional academic advisors support the development of students' cultural identities as existing members of a global world as they transition to and through college? Hagen and Jordan (as cited in Grites, 2013) stated that "theory-building based on advising as teaching has not reached its peak" (p. 12). Given these limitations of the learning-centered paradigm, I borrow from resource pedagogy research to extend the learning-centered concept to reflect the 
methods needed to more effectively support the retention and degree completion of students of color in higher education.

\section{Culturally Sustaining Pedagogy}

Deficit approaches during the 1960s and 1970s viewed the cultural practices and ways of being of many students and communities of color as deficiencies to be overcome in learning the dominant language, literacy, and cultural ways of schooling (Paris, 2012). Languages and literacies that fell outside of White, middle-class norms were seen as lessthan and unworthy of a place in American schools and society (Paris, 2012). LadsonBillings' (1995) work built on earlier anthropological and sociolinguistic attempts to create a match between the student's home culture and school culture. Ladson-Billings (1995) argued that "a theory of culturally relevant pedagogy would necessarily propose to do three things - produce students who can achieve academically, produce students who demonstrate cultural competence, and develop students who can both understand and critique the existing social order" (p. 474). Her forward thinking contributed to discussions about the importance of using terminology that better embodies the proficiencies essential for working in diverse communities.

Paris (2012) stated that the term culturally relevant pedagogy does not support the linguistic and cultural skillfulness necessary for success and access in our rapidly changing U.S. and global schools and communities. Instead, Paris (2012) suggested the term culturally sustaining pedagogy:

...requires that our pedagogies be more responsive of or relevant to the cultural experiences and practices of young people - it requires that they support young 
people in sustaining the cultural and linguistic competence of their communities while simultaneously offering access to dominant cultural competence (p. 95). In summary, the learning-centered paradigm offers guiding principles for how professional academic advisors can facilitate student learning about the mission of the institution, critical thinking skills, and critical self-reflection in preparation for existence in a complex global world. What is not clear about this newer advising approach is how a professional academic advisor can also facilitate a student of color's learning about their cultural identities and the identities of those around them so as to not encourage the abandonment of their pre-college cultural memberships. To advise a student holistically includes acknowledging, sustaining, and developing a student's identity, language, and skills. Paris' (2012) concept of culturally sustaining pedagogy supports and advances the call to the academic advising field to not only advise the whole student, but to also support the student in sustaining the cultural competencies of their pre-college communities. The following section considers how multicultural competencies can provide more concrete ways for professional academic advisors to integrate learningcentered advising with culturally sustaining pedagogy.

\section{Multicultural Competence in Helping and Advising}

Since the socio-political context and diversity of students arriving on college campuses has changed drastically over the years, and because of the nature of the complexities they bring with them to college campuses, academic advisors must be educated about underrepresented groups to have the ability to build culturally responsive relationships with these students (Cunningham, 2003; Gilbert, 2005, Harding 2012). Academic advisors can be cultural translators and aid in the retention and degree 
completion for students of color. One perspective that shapes how academic advisors provide meaningful and relevant services to students of color is Pope and Reynolds' (1997) characteristics of a multiculturally competent student affairs practitioner. Pope and Reynolds (1997) presented thirty-two characteristics of a multiculturally competent student affairs practitioner as a starting place for practitioners to examine their own levels of awareness, knowledge, and skills in the core competencies for student affairs professionals (see Table 3 in Appendix B). The list of characteristics is not exhaustive, and it is linked to the ethical principles shared by the Council for the Advancement of Standards in Higher Education (CAS).

Pope and Reynolds (1997) argued that to be an effective student affairs professional, one must possess the awareness, knowledge, and skills necessary to communicate and support individuals within cultures similar to and different from one's own. This perspective is based on literature from Sue et al. (1982), which called for cross-cultural competencies in the counseling field, as well as multiple pleas to make college campuses more welcoming and multiculturally sensitive (Astin, 1992; Ebbers \& Henry, 1990; Reynolds \& Pope, 1994). The Dynamic Model of Student Affairs Competence (Pope, Reynolds, \& Mueller, 2004) represents the seven core competencies for good student affairs practice (administrative and management, theory and translation, helping and interpersonal, ethical and legal, teaching and training, assessment and evaluation, and multicultural awareness, knowledge, and skills). Although each competency is arranged to build on the other, the model does account for how one competency may influence another. Figure 3 provides a visual representation for these core competencies. 


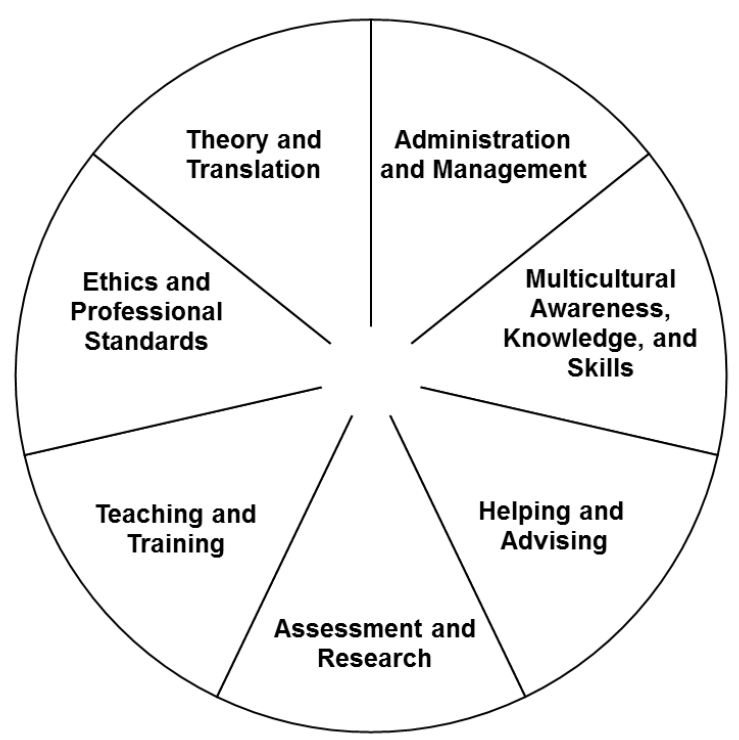

Figure 3. The Dynamic Model of Student Affairs Competence. Source: Adapted from Pope, Reynolds, and Mueller (2004, p. 10).

Reynolds and Pope (2003) also offered a list of seven multicultural competencies specific to practitioners in helping and advising roles. These are the seven multicultural competencies suggested by Reynolds and Pope (as cited in Pope, Reynolds, \& Mueller, 2004):

1. An awareness, appreciation, and understanding of cultural groups, specifically those groups that have been historically underrepresented.

2. Increasing content knowledge about culturally related terms such as racial identity, acculturation, or worldview.

3. Improving awareness of one's own biases and cultural assumptions.

4. Developing the ability to use that knowledge and self-awareness to make more culturally sensitive interventions.

5. Developing an awareness of the interpersonal dynamics that may occur.

6. Unpacking the cultural assumptions underlying the counseling process. 
7. Applying advocacy skills to assist in the development of a more multiculturally affirming campus (adapted from Pope, Reynolds, \& Mueller, 2004, pp. 85-86).

Hemwall and Trachte (1999) claimed that through the practice of advising-asteaching, academic advisors could help all students think critically and analytically about the social structures they live within. And yet, as to how academic advisors teach students about the beliefs, norms, and assumptions that give meaning to our world, the principles offered by Hemwall and Trachte (2005) do not help advisors operationalize the principles into practice. Reynolds and Pope's (2003) seven multicultural competencies for practitioners in helping and advising roles describe the abilities required to (a) sustain the pre-college identities students of color bring with them to college, and (b) facilitate critical thinking among all students about the cultural practices and systems in our society. Nevertheless, the degree to which an academic advisor must be proficient in these abilities remains unclear.

Harding (2008) argued it is crucial for advisors to realize their own level of cultural competency in addressing the concerns and issues of their advisees. Harding (2008) stated that as individuals on the front line, academic advisors must examine their own levels of intercultural awareness. He offered the following levels of intercultural awareness as a baseline for understanding how to better identify and relate to diverse students and their needs: (a) non-awareness, (b) awareness of difference, (c) acceptance/acknowledgement, (d) understanding cultural difference, (e) cultural adaptation, and (f) intercultural skillfulness. Moreover, Harding (2008) claimed there are four components of a culturally competent advisor and these include awareness, 
knowledge, skill, and respect. Harding (2008) extended Reynold and Pope's (2003) list of multicultural competencies by adding respect and stated that without respect "awareness, knowledge, and skills become just tools and not an ideology that is internalized and applied" (p. 192).

The conceptual framework presented in this chapter offers a theory-to-practice perspective and supports how professional academic advisors, in particular, can translate their knowledge in ways that students of color can interpret and apply to their postsecondary experience. Existing literature about competencies that promote successful advising practice is reviewed in the next section.

\section{Literature Review}

When delivering one-to-one advising, Fox (2008) suggested that there are five C's of a skilled academic advisor. Fox (2008) postulated these are the skills needed to forge a strong, continuous relationship with an advisee and include: (1) competence, (2) confidence-building, (3) cordiality, (4) credibility, and (5) creativity. Fox (2008) suggested that an additional "C" that may be a key consideration for the skilled advisor include culture, because:

The competent, credible faculty advisor, the caring creative professional advisor, will incorporate what the student brings from her culture to the advising session. The advisor will make use of the history introduced, and will validate the family patterns and beliefs that may impact the student's academic experience (p. 350).

Shaffer (1998) described the growing demand for multicultural competence as a component of human capital in the growing economy. He defined multicultural competence as "an understanding of international business and social relations plus the 
attitudes, skills, and special knowledge necessary to apply it” (p. 21). Shaffer (1998) urged academic advisors to help students maximize their human capital by developing multicultural competence skills as part of their postsecondary educational experience. Shaffer (1998) conceptualized human capital as the "skills and special knowledge necessary to make a worker productive in a particular occupation" (p. 22). Shaffer (1998) argued that for students to understand a culture in multiple ways, it is not simply enough to have an awareness of that culture. Students must be able to work effectively with others from non-American backgrounds.

Consequently, Shaffer (1998) discussed several strategies advisors can employ to develop multicultural competence among students based on Garcia's (as cited in Shaffer, 1998) training approach that operationalizes multicultural competence as four interrelated skills:

1. Understanding culture as it operates on different social levels;

2. Understanding common barriers to effective communication and relationships;

3. Developing personal competencies, dialogue, and recovery skills for effective communication and relationship building;

4. Developing strategies for problem solving and for transforming an organization into a multicultural organization (Shaffer, 1998, p. 22).

Garcia (as cited in Shaffer, 1998) suggested multiple personal competencies identified as important for working with persons in diverse settings including being nonjudgmental, flexible, and resourceful; attentively listening, tolerating ambiguity, displaying empathy, and maintaining a sense of humor. Shaffer (1998) stated that more 
often than not, academic advisors must help students identify multicultural and diversity courses from the general education curriculum.

One of the limitations in Shaffer's (1998) work is that although he described the importance and urgency of multicultural competence among students in a growing global economy, he did not focus as much on the specific multicultural competencies academic advisors must employ in their advising practice to facilitate such competencies among students. Cornett-DeVito and Reeves (1999) addressed this limitation head-on by presenting findings from a review of the counseling, advisement, and intercultural communication literature associated with multicultural competence and the modeling role of the advisor.

Cornett-DeVito and Reeves (1999) echoed earlier arguments that academic advisors can play an instrumental role in helping students structure their college experiences to include both social and academic interactions with people who are culturally different from themselves. The article is organized into subsections that focus on particular strategies academic advisors can use to increase their multicultural competence, including negotiating advisor-advisee roles, rapport building that acknowledges perceived power differences, and recognizing cultural differences between advisors and their advisees (p. 36). Cornett-DeVito and Reeves (1999) concluded that more research is necessary to increase an understanding of how academic advisors from diverse backgrounds can model competent intercultural communication with a diverse student advisee population. Cornett-DeVito and Reeves (1999) stated that, "To date, the advisement literature has been too generic, with little regard for cultural differences between advisors and advisees" (p. 42). They add that although the current multicultural 
literature is important, it tends to focus on the experiences between White academic advisors and students of color (p. 42).

\section{Research about Advising Competencies}

Based on a storytelling methodology, Fiddler and Alicea (1996) conducted a study about advising competencies developed from an examination of faculty and staff in the School of New Learning at DePaul University (Chicago) who advise adult learners. ${ }^{1}$ The process included 35 members (i.e., administrators, faculty members, and advisors) via two 3.5 hour workshops to draw competencies based from their own experiences. Fiddler and Alicea (1996) found that the overall focus on abilities that provide a supportive environment for learning rather than on expertise in various areas of knowledge gives emphasis to a commitment to learning-centeredness (p. 17). Five main competencies and corresponding abilities were revealed, and although the researchers report that these competencies were not new to the faculty and staff participants in the study, the recognition of these competencies underscored their importance to the unit. The competencies include: (a) planning and organizing, (b) assessment, (c) communication and counseling, (d) teaching and learning/facilitating learning, and (e) professional values, ethics, and development. Of particular interest is the competency "communication and counseling" because the researchers note that the advising abilities are based on respect for the individuality of each learner and the goal of developing trust and rapport with a diverse population of students.

While the study uses qualitative methods to organize, assess, and align advising experiences with practices, it omits student perceptions of good advising practices and it does not report on the demographic composition of its participants. The assumption,

\footnotetext{
${ }^{1}$ The researchers define adult learners as students whose age is equal to or greater than 24 years old.
} 
then, is that the competencies and abilities derived from the unique experiences of the administrators, faculty, and advisors in this study may affect general advising practices in the academic advising field. Not only does this assumption run counter to the aim of qualitative research, which is to deepen and enrich (instead of generalize) one's understanding of some aspect of social life that cannot be otherwise obtained through quantitative methods, but it also provides a space for criticism because the researchers do not report on how the advising experiences of the participants may be based, in part, on the intersections of their cultural identities.

Bloom, Cuevas, Hall, and Evans' (2007) grounded theory study about graduate students' perceptions of outstanding graduate advisor characteristics also uncovered five traits to be most helpful in their advising practice: (a) demonstrated care for students, (b) accessibility, (c) role models in professional and personal matters, (d) individually tailored guidance, and (e) proactive integration of students into the profession. Conducted at the University of Illinois at Urbana-Champaign and based on a qualitative textual analysis of the written advisor nominations MD-PhD students submitted for the Medical Scholars Program Outstanding Graduate Advisor of the Year Award program from 2001 to 2003, the researchers contend that the five themes support the notion that graduate advisors play a significant role the graduate student's academic life. Like Fiddler and Alicea's (1996) study, Bloom et al. (2007) did not report the demographic traits of the study participants. However, the researchers addressed this limitation and justified its absence based on maintaining the advisors' anonymity and confidentiality in the study. Bloom et al. (2007) further supported their decision to not report graduate advisors' backgrounds by recommending that future studies should examine the 
differences in advising characteristics between male and female advisors and how advisor or student gender might influence students' perceptions of outstanding advisors. On the one hand, this recommendation does acknowledge that differences between gender may exist and influence perceptions of outstanding advisors. On the other hand, the researchers fail to address how differences may exist among other demographic traits, such as race/ethnicity, and how these differences may influence perceptions.

Harrison's (2009) qualitative content analysis at a state university in southeastern Minnesota examined nursing students' perceptions of the characteristics of effective academic advisors. Thirty nursing students and 33 pre-nursing students were surveyed. The results were counted individually for nursing and pre-nursing students, and then combined to reflect one list of characteristics of effective academic advisors. Although the students did not rank their responses, the researcher ordered the qualities based on frequencies. Being knowledgeable, fostering and nurturing, possessing moral virtue, and having good communication skills were identified as characteristics of effective academic advisors as well as the qualities of being approachable, available, organized, and authentic. No demographic data were collected for this preliminary study.

Main findings from a meta-analytic review I conducted in 2013 revealed that characteristics of advising skills can be organized into three categories to determine three estimates of satisfaction with advising: (a) comprehension of institutional and degree requirements, policies, and procedures; (b) interpersonal communication; and (c) advising techniques/approaches (see Tables $4-6$ in Appendix B). These categories are particularly consistent with the larger body of relevant literature about academic advising competencies. There was a statistically significant moderate correlation between each of 
the characteristics of advising skills and student satisfaction with advising, and advising techniques/approaches had the largest of the three correlations with satisfaction with advising. What is most significant to discuss about these findings is what was absent from them. Although estimates of characteristics of advising skills related to student satisfaction were generated, they were based on a predominantly White female sample of students with an average age of 18 years. This outcome is consistent with the results reported in the 15 articles coded for the meta-analytic review. Many articles do not include communities of color in their samples, nor do they report the demographic information for all racial/ethnic groups represented in a sample. Therefore, not only is there ambiguity about the characteristics of advising skills students of color are satisfied with, but there is also a gap in the advising literature about the characteristics associated with higher levels of multicultural competence.

Academic advisors can serve in many roles for different students at different types of postsecondary institutions. Tan (1995) stated that a role model can be a faculty member, an administrator, an academic advisor, or another individual the student looks up to and has regular interactions with. He added that a role model can be especially effective in assisting minority students develop a sense of self and dealing with issues such as stereotyping and racial prejudice. In his 1995 study about the extent of interaction with role models among minority students on a predominantly White campus, Tan (1995) found that while the majority of his participants perceived the importance of having a role model as significant, many students did not have one. When the randomly sampled participants, which included 78 Asian American students and 66 African American students at a large, public, research university in the Southwest United States, 
were asked whether it was a requisite for the role model to be of the same racial identity as the students, not a single Asian American student responded that the role model had to be of the same race, but $18 \%$ of African American students said that the role model should be of the same race. In both student groups, $27 \%$ of students indicated no preference for a racially matched role model. Furthermore, Tan (1995) found no relation between students' perception of the importance of role models and their levels of satisfaction with academic and social experiences on campus. Tan (1995) stated one possible explanation for this finding, and in terms of the social experience on campus more directly, was that Asian American students found social norms and values on campus to be similar to their own. Although Tan (1995) reported that the findings were preliminary and inconclusive due to the low and shifting number of cases in the study, he emphasized that the differentiated findings for the groups may be a result of the degree of normative congruence between these students and the campus.

The findings in this study, for Asian American students specifically, support the claim that students with pre-college memberships and cultural affiliations consistent with those of the institution, may be more socially and/or academically integrated into the campus community and, as a result, may not require the same types of support and guidance from a role model that African American students may need. Even though Tan's (1995) study did not outline specific proficiencies a role model should have to work directly with students of color, it did include recommendations for the future including more attention directed to the recruiting, hiring, and training of faculty members who are willing to serve as role models to handle social and academic issues faced by minority students on predominantly White campuses. 
Shultz, Colton, and Colton (2001) attempted to address these recommendations by reporting the findings of a pilot intervention initiative fusing academic advising and mentoring into a proactive model. They posited that successful support systems for students of color include proactive interventions, intrusive advising and counseling, developing personal support networks, and cultivating mentoring relationships with faculty. In the fall of 1995, the College of Education at Kutztown University, a public, midsized, predominantly White institution in eastern Pennsylvania, designed a program aptly named the Adventor Program based on its emphasis of academic advising and faculty mentoring. The program recognized that faculty must become sensitive to the cultural and ethnic backgrounds among students of color, and understand some of the commonalities that exist among this population of students. Furthermore, faculty needed to know how their own perceptions and biases interacted with these commonalities. The faculty volunteers in this program participated in a multiple-session orientation workshop designed to facilitate culturally sensitive relationships. Faculty participants were able to explore their biases through role-playing, using the interpersonal skills they learned regarding diversity.

The Adventor program also addressed the needs of students of color. These students often experience difficulty when seeking academic assistance, and repeatedly feel ashamed about having academic issues or asking for help (Shultz, Colton, \& Colton, 2001). Contrary to traditional academic advising practices in which students initiate contact with an academic advisor, the Adventor Program used intrusive tactics to reach out to students of color such as mandatory weekly meetings, personal contacts, emails, telephone calls, and letters throughout the year, in an attempt to retain a diverse body of 
students. The authors argued that students participating in the Adventor Program benefitted from the unique nurturing and mentoring relationship with faculty. They received academic and emotional support services that assisted them in developing more confidence in their academic ability and skills to deal with peer rejection, and any effects of racism and discrimination they may experience on campus. Through the program, Adventor students were able to "identify and become appropriately integrated into the academic and social cultures of Kutztown University" (p. 212).

Shultz et al. (2001) concluded that end of the year program assessment results indicated that students of color enjoyed their advising/mentoring experience, and that students of color believed the faculty assisted them with their transition to college. Seventy-seven percent of the pilot Adventor student returned for a second year of study. The authors suggested that the pilot program needed to be replicated in a longitudinal design with larger sample sizes to better determine the effects of the program.

Whereas Shultz et al. (2001) focused on the role of faculty advisors, Museus and Ravello (2010) contributed to the existing body of literature about how professional academic advisors contribute to the success of students of color at predominantly White institutions. Using qualitative techniques, Museus and Ravello (2010) identified 45 participants, including 14 academic advisors and 31 racial and ethnic minority (9 Asian American, 9 Black, and 13 Latina/o) students across three institutions they identified as generating ethnic minority success (GEMS). The criteria for selecting the three institutions in their study was based on (a) a graduation rate among underrepresented racial and ethnic minority students that was higher than the national average, (b) graduation rates among underrepresented racial and ethnic minority students that were 
close to or greater than those of their White counterparts, and (c) a White student enrollment of approximately $50 \%$ or more.

Museus and Ravello (2010) reported on three emergent themes. First, participants noted the importance of academic advisors who cared about being committed to the success of students of color, or humanizing the practice of academic advising. Second, Museus and Ravello (2010) highlighted the impact of academic advisors who made efforts to advise the whole student. This included being aware that a minority students' issues are not isolated (e.g., academic, personal, and financial), and ensuring that minority students received the support they needed, regardless of the nature of their issues. Finally, interview participants underscored the importance of proactive academic advisors. These advisors made both informal and systematic efforts to connect students of color with the resources they needed to succeed.

\section{Academic Advising Competencies Summary}

Past studies about academic advising competencies reveal that academic advisors and the skills they use in practice have a significant impact on the students they advise. Three important themes that emerged from the relevant literature suggest: First, students perceive a skilled advisor to possess strong interpersonal skills, a deep understanding of institutional and degree requirements, and a teaching/facilitating orientation to advising practice; Second, it is difficult to ascertain which student characteristics are correlated to preferred advising competencies because several of the studies did not report descriptive data on the participants sampled; Third, findings from studies about advising students of color attending predominantly White institutions indicated that students of color value the 
importance of having a proactive and committed advisor, with most having no preference for racial matching.

Two additional findings from the review of advising literature identified areas for further investigation. First, is how the use of the construct "satisfaction" is often muddled with "effectiveness." Are the advising skills students perceive to be effective the same as the advising skills students are satisfied with in actuality? Does satisfaction with a skill lead to successful practice? Not only does the blurring of these terms reveal an inconsistency among the advising literature, but confounding these terms with one another poses a challenge for framing the advising competencies that lead to good practice.

Second, a scarcity of empirical studies investigates academic advising with students of color. Results from Tan's (1995) study demonstrate that some students of color with pre-college cultural affiliations consistent with those of the institution may be more socially and/or academically integrated into the campus community. For other students of color, learning how to navigate new college norms, values, and behavioral styles that are different from those typically associated with the family, high school, or community may require unique support. As Rendón et al. (2000) held, navigating two worlds requires effort from both the student and the institution. Academic advisors are instrumental in facilitating the development of a students' unique cultural and linguistic background while transitioning to and through college.

It is evident from the advising literature that multicultural competence is essential when advising students with cultures similar to and different from one's own. It is also clear that although extant advising literature discussed the importance of developing 
awareness, knowledge, and skills to support the holistic growth of students for several years, it did so with little regard for how academic advisors can (a) determine and assess their own levels of multicultural competence, and (b) examine how these levels impact relationships between advisors and advisees. This section highlighted not only the ethical importance of possessing the awareness, knowledge, and skills necessary in academic advising, but it also underscored the importance of applying these skills when advising students of color.

\section{Chapter Summary}

Ethical, effective academic advising requires that advisors advise the whole student. Such practice requires recognition of cultural differences and perceived power differences, upholding pre-college cultural affiliations and traditions, empathizing with students, and advocating on behalf of students. Several studies reveal a variation of techniques and approaches students are either satisfied with or perceive to be excellent. Few studies report the techniques and approaches students of color value. This chapter offered a comprehensive review of position pieces and empirical studies that conceptualized academic advising-as-teaching and multicultural competence in helping and advising. The next chapter explains the methodology selected for the study. 


\section{CHAPTER III METHODOLOGY}

The purpose of this study was to determine if statistically significant relationships existed between participant attributes and their multicultural competence score at a large, public, urban research institution in the southern United States. In this chapter, I describe the research design, population and sample, as well as data collection and analysis techniques. I also expand upon the development of the Multicultural Competence in Student Affairs - Preliminary 2 (MCSA-P2) instrument and conclude with limitations to this study.

\section{Research Design}

A survey research design was selected for systematically gathering information from a sample of participants at a four-year metropolitan institution for the purposes of: (a) assessing the multicultural competence of academic advising professionals, and (b) identifying relationships between data collected. It is advantageous to use survey design when a researcher has limited resources, such as time and monetary funding (Dillman, Smyth, \& Christian, 2009). Another benefit of using survey design is that it is easier to obtain a survey sample than an experimental design sample, usually leading to higher response rates than in experimental research (Dillman, Smyth, \& Christian, 2009).

\section{Population and Sample}

References to the institution selected in this study were masked as much as possible to preserve the anonymity of both the institution and the participants at the 
institution. The main campus was located downtown in an urban city. There were a total of 67 University professional advisors and advising center directors representing nine schools and colleges, including: (1) College of Arts and Sciences, (2) College of Business, (3) College of Education and Human Development, (4) School of Engineering, (5) School of Social Work, (6) School of Dentistry, (7) School of Music, (8) School of Nursing, and (9) School of Public Health (N. Scobie, personal communication, April 10, 2014). There were 16 enrolled students in the Doctor of Philosophy program in the counseling and personnel services preparation program, and 287 graduates of the Master of Education in counseling and personnel services preparation program since 1992 (J. Cox, personal communication, May 1, 2014). The population for this research study was defined as advising professionals, current and recent doctoral students, and current and recent master's students in a counseling and personnel services preparation program at the University between Spring 2012 and Spring 2014.

\section{Variables}

The variables used in this study were drawn from relevant research cited in chapters one and two. Background variables representing advisor personal attributes were: gender identity, racelethnicity, engagement with populations different from one's own racial identity, highest degree completed by a parent/guardian, and sexual orientation. Race/ethnicity, highest degree completed by a parent/guardian (used as a proxy for first-generation status), and sexual orientation were included to determine association with a socially marginalized group and/or an underrepresented group (Jones, 2013; Mueller \& Pope, 2001). Background variables representing advisor professional 
attributes were: years of professional experience, academic degree level, and frequency

of participation in multicultural coursework and training.

The dependent variable, multicultural competence score, was selected based on its relation to academic advising ethical principles and student of color success. For a complete list of variables with levels of measurement and coding, see Table 7.

Table 7

Independent Background and Dependent Variables

\begin{tabular}{|c|c|c|c|}
\hline $\begin{array}{l}\text { Type of } \\
\text { Variable }\end{array}$ & Variable & $\begin{array}{l}\text { Scale of } \\
\text { Measurement }\end{array}$ & Coding \\
\hline \multirow{5}{*}{$\begin{array}{l}\text { Independent } \\
\text { Personal } \\
\text { Attribute }\end{array}$} & Gender Identity & $\begin{array}{l}\text { Categorical } \\
\text { (nominal), } 5 \text { levels }\end{array}$ & $\begin{array}{l}1=\text { Male; } 2=\text { Female; } 3=\text { Non- } \\
\text { binary; } 4=\text { Not listed; } 5=\text { I prefer } \\
\text { not to answer }\end{array}$ \\
\hline & Race/Ethnicity & $\begin{array}{l}\text { Categorical } \\
\text { (nominal), } 9 \text { levels }\end{array}$ & $\begin{array}{l}1=\text { American Indian/Alaskan } \\
\text { Native; } 2=\text { Asian; } 3=\text { Native } \\
\text { Hawaiian or Pacific Islander; } 4= \\
\text { Black or African American; } 5= \\
\text { Hispanic or Latino/a; } 6=\text { Two or } \\
\text { More Races; } 7=\text { White; } 8=\text { Not } \\
\text { listed; } 9=\text { I prefer not to answer }\end{array}$ \\
\hline & $\begin{array}{l}\text { Engagement with } \\
\text { Populations } \\
\text { Different from } \\
\text { Own Race }\end{array}$ & $\begin{array}{l}\text { Continuous } \\
\text { (ordinal), } 6 \text { levels }\end{array}$ & $\begin{array}{l}1=\text { Once } ; 2=\text { Daily } 3=\text { Weekly; } \\
4=\text { Monthly } ; 5=\text { Semi-annually; } 6 \\
=\text { Annually }\end{array}$ \\
\hline & $\begin{array}{l}\text { Highest Degree } \\
\text { Completed by a } \\
\text { Parent/Guardian }\end{array}$ & $\begin{array}{l}\text { Continuous } \\
\text { (ordinal), } 8 \text { levels }\end{array}$ & $\begin{array}{l}1=\text { HS diploma or equivalent; } 2= \\
\text { Technical, trade, or vocational } \\
\text { training; } 3=\text { Associate's degree; } 4 \\
\text { = Bachelor's degree; } 5=\text { Master's } \\
\text { degree; } 6=\text { Doctor's degree; } 7= \\
\text { Professional degree; } 8=\text { Not listed }\end{array}$ \\
\hline & Sexual Orientation & $\begin{array}{l}\text { Categorical } \\
\text { (nominal), } 8 \text { levels }\end{array}$ & $\begin{array}{l}1=\text { Lesbian; } 2=\text { Gay; } 3= \\
\text { Bisexual; } 4=\text { Queer; } 5= \\
\text { Questioning; } 6=\text { Straight; } 7=\text { Not } \\
\text { listed; } 8=\text { I prefer not to answer }\end{array}$ \\
\hline
\end{tabular}

(Continued) 
Table 7 Continued.

\begin{tabular}{|c|c|c|c|}
\hline $\begin{array}{l}\text { Type of } \\
\text { Variable }\end{array}$ & Variable & $\begin{array}{l}\text { Scale of } \\
\text { Measurement }\end{array}$ & Coding \\
\hline \multirow{3}{*}{$\begin{array}{l}\text { Independent } \\
\text { Professional } \\
\text { Attribute }\end{array}$} & $\begin{array}{l}\text { Years of } \\
\text { Professional } \\
\text { Experience }\end{array}$ & Continuous (ratio) & \\
\hline & $\begin{array}{l}\text { Academic Degree } \\
\text { Level }\end{array}$ & $\begin{array}{l}\text { Continuous } \\
\text { (ordinal), } 8 \text { levels }\end{array}$ & $\begin{array}{l}1=\text { HS diploma or equivalent; } 2= \\
\text { Technical, trade, or vocational } \\
\text { training; } 3=\text { Associate's degree; } 4 \\
\text { = Bachelor's degree; } 5=\text { Master's } \\
\text { degree; } 6=\text { Doctor's degree; } 7= \\
\text { Professional degree; } 8=\text { Not listed }\end{array}$ \\
\hline & $\begin{array}{l}\text { Frequency of } \\
\text { Multicultural } \\
\text { Training }\end{array}$ & $\begin{array}{l}\text { Continuous } \\
\text { (ordinal), } 6 \text { levels }\end{array}$ & $\begin{array}{l}1=\text { Once } 2=\text { Daily } ; 3=\text { Weekly; } \\
4=\text { Monthly; } 5=\text { Semi-annually } 6 \\
=\text { Annually }\end{array}$ \\
\hline $\begin{array}{l}\text { Dependent } \\
\text { Variable }\end{array}$ & $\begin{array}{l}\text { Multicultural } \\
\text { Competence Score }\end{array}$ & $\begin{array}{l}\text { Continuous } \\
\text { (ordinal) }\end{array}$ & \\
\hline
\end{tabular}

\section{Research Setting}

The study was conducted at a large, four-year public metropolitan research institution located in the southern United States. The university has three campuses and 12 colleges and schools. Approximately 22,000 students attend the university, with the majority of the enrollment at the undergraduate level (71\%). Males represent approximately $48 \%$ of the total student population, whereas females represent $52 \%$ of the same population. According to the online University Profile, the majority of the student population identifies as White (74.7\%), followed by African American (10.4\%), and other racial/ethnic minorities $(9.7 \%)$. Additional data for other racial/ethnic minority student groups were not disaggregated or reported. Finally, international students comprise $5.2 \%$ of the total student body (citation omitted for anonymity). 
The mission of the institution is to be nationally recognized as a premier metropolitan research university with a commitment to the liberal arts and sciences and to the intellectual, cultural, and economic development of its diverse communities and citizens. To accomplish this, the University focuses on the following five areas: (1) educational experience, (2) research, creative and scholarly activity, (3) accessibility, diversity, equity, and communication, (4) partnerships and collaborations, and (5) institutional effectiveness of programs and services (citation omitted for anonymity).

The institution's stated philosophy of academic advising reflects a belief that student success is a comprehensive, institutional responsibility, and it values teaching and learning as an academic function. Moreover, the philosophy holds a belief in fostering the individuality and diversity of students and their unique educational needs and experiences (citation omitted for anonymity).

The executive director for the undergraduate advising office reports to the viceprovost for Undergraduate Affairs. The undergraduate advising office, comprised of a six-member team, works collaboratively with the undergraduate academic units to promote consistent and best practices in academic advising. The organizational structure and attendant model for delivering undergraduate advising services at this institution can be best described as decentralized and shared, respectively (Pardee, 2004). This model designates that professional or faculty advisors are located within each one of 12 colleges and schools, and either professional or faculty advisors, or a combination of the two, advise students enrolled in that particular unit. Advising center directors provide oversight of the professional or faculty advisors located in each unit. First-time, full-time undergraduate students, and transfer students with fewer than 24 hours completed, are 
assigned to a professional academic advisor when the student matriculates to the institution. Advising assignments vary based on the academic unit a student's program plan is offered by and the student's admission status. In most academic units, students are assigned to the same professional academic advisor through degree completion.

\section{Sampling Procedures}

Quantitative sampling techniques were employed to address the research questions in this study. In an email to all undergraduate academic advising professionals, current and recent doctoral students, and current and recent master's students in the College Student Personnel program $(\mathrm{N}=162)$, I stated that I was conducting a survey study about multicultural competence in academic advising approved by the Institutional Review Board (IRB) (see Appendix C). I indicated that participation in this study was completely confidential and voluntary, and if members wanted to participate in this study to click on the Qualtrics survey link included in the email. The online survey was made available for ten days during the months of June and July. Respondents who did not complete the survey after four days from the initial email invitation received a second email soliciting their participation and focusing on the short amount of time that was left to complete the survey and the importance of responding. I used convenience sampling and a volunteer sample in this study.

\section{Participants}

The participants were undergraduate professional academic advisors, current and recent doctoral students, and current and recent graduate students in the College Student Personnel program at a large, metropolitan research institution in the southern United

States. Participants were selected based on their current roles as professional advisors or 
supervisors of professional advisors, their role as a student affairs professional in functional areas of campus who work directly with academic advising or students seeking a career in academic advising or student affairs.

\section{Data Collection Procedures}

A demographic section of the web survey included 27 questions including questions that specifically addressed personal background attributes (e.g., gender identity, race/ethnicity, engagement with populations different from one's own racial identity, highest degree completed by a parent/guardian, and sexual orientation) and professional background attributes (e.g., years of professional experience, academic degree level, and frequency of participation in multicultural coursework and training) (see Appendix C). The demographic form was used to describe the sample, determine independent variables, and preceded the Multicultural Competence in Student Affairs - Preliminary Form 2 described in the next section.

\section{Multicultural Competence in Student Affairs - Preliminary Form 2}

Pope and Mueller (2000) developed a measure of student affairs multicultural competence with the Multicultural Competence in Student Affairs-Preliminary Form 2 (MCSA-P2). This instrument was chosen because it was designed specifically for evaluating multicultural awareness, knowledge, and skills in a higher education context. It is currently the only available instrument designed to assess the multicultural competence of those who work in student affairs (Pope \& Mueller, 2000). This 34-item instrument is arranged using a Likert-type self-report scale, measuring individual responses to items where 1 equals "Not at all accurate" and 7 equals "Very accurate" (see Appendix C). A single, total score on the scale measures the construct "multicultural 
competence." The internal consistency reliability coefficient, Cronbach's alpha, reported for this instrument ranges from .91 to .961 (Franklin, 2010; Pope \& Mueller, 2000).

Pope and Mueller (2000) conducted a study to critically assess the instrument. The sample for the study consisted of 190 student affairs personnel from diverse backgrounds in different functional areas, at multiple levels of education and years of experience. The researchers asked the participants to complete a personal data form, the MCSA-P2, a Social Desirability Scale (SDS), and the Quick Discrimination Index (QDI). Pope and Mueller (2000) described the SDS as a 33-item, true-false inventory designed to measure one's approval-seeking behavior. The researchers described the QDI as a 30item, Likert-type self-report inventory that measures attitudes about racial diversity and gender issues.

The results of the initial test and validation of the MCSA-P2 revealed a high level of internal consistency with a Cronbach's alpha of .91. The coefficient alphas for the SDS (.82) and QDI total scale (.87) were found to be high and the researchers determined that the instruments were appropriate for use in their study. The results of the Pearson product-moment correlations between the MCSA-P2 and the QDI demonstrated a positive and significant correlation $(r=.66 ; p<.01)$ indicating that those who are more sensitive and more aware of racial and gender issues are also more multiculturally competent. The results of the Pearson product-moment correlation analysis between the MCSA-P2 and the SDS showed a minimal $(r=-.01)$ and non-significant correlation indicating that social desirability contamination was not a concern (Pope \& Mueller, 2000). 
Research on the MCSA-P2. There is some evidence to suggest that certain variables such as personal identification with a socially marginalized group and experience with training of multicultural programs are related to multicultural competence (Franklin, 2010; Mueller \& Pope, 2001; Pope, Reynolds, \& Mueller, 2004; Porter, 2011). In one study, Mueller and Pope (2001) examined multicultural competence in relation to White racial consciousness. Findings from the study reveal a strong relationship between racial consciousness and multicultural competence among White student affairs practitioners. The researchers concluded that less avoidance of, less certainty about, and less ethnocentric attitude toward racial issues seems to be related to multicultural competence. They also discovered that other variables among White practitioners such as discussions with supervisors about multicultural issues and interest in and a desire to work with diverse students and colleagues were also related to multicultural competence (Mueller \& Pope, 2001).

In an unpublished dissertation, Franklin (2010) used the MCSA-P2 along with other instruments to introduce to the field of student affairs a new theoretical construct (Cultural Intelligence or CQ) and assessment instrument (Cultural Intelligence Survey) designed to assess intercultural competency. This newer construct and instrument are used to address a series of research questions designed to be better understand the intercultural competency of a sample of student affairs administrators.

In another unpublished dissertation, Porter (2011) used the MCSA-P2 to determine if statistically significant relationships existed between multicultural competence and a series of independent variables among select student affairs administrators at member institutions of the Council for Christian Colleges and 
Universities. Participants for this study included 115 student affairs administrators among 33 Christian colleges and universities in 17 states. Findings from this study demonstrate that race, participation with diversity training, and professional level were significantly linked to higher mean multicultural competence scores $(\mathrm{p}<.05)$.

Rationale for the use of the MCSA-P2. I chose to use a demographic questionnaire and the MCSA-P2 to address (a) the gaps in the advising literature regarding multicultural competence, and (b) to examine the relationship between personal and professional attributes and experiences that may account for differing levels of multicultural competence. Combining the MCSA-P2 with pertinent demographic information about participants will provide a more complete picture of the attributes related to multicultural competence and will better inform the academic advising field about ethical and equitable advising practice.

\section{Data Collection}

I sent participants a link to the web survey via their institutional or personal email account. The web survey, which included the demographic questionnaire and the MCSA-P2, was administered via Qualtrics for ten days in the months of June and July, and data were collected using a web survey method. Based on a preliminary field test of the instrument, the web survey took approximately 10 to 15 minutes to complete, and no incentive was provided.

\section{Data Analysis and Research Questions}

I analyzed all data using the Statistical Package for the Social Sciences (SPSS). Since I was interested in drawing inferences about academic advisors, advising center directors, current and recent doctoral students, and current and recent graduate students in 
a counseling and personnel services preparation program at an urban research institution based on a sample from this population, I used both descriptive and inferential statistics to conduct this study. Once the data were collected, I examined frequency distributions to inform which variables to include in further analyses, and how to collapse and recode variables. To answer my first three research questions, an exploratory univariate regression analysis was performed between the dependent variable (multicultural competence score) and the independent variables (gender identity, racelethnicity, engagement with populations different from one's own racial identity, highest degree completed by a parent/guardian, sexual orientation, years of professional experience, academic degree level, and frequency of participation in multicultural coursework and training). Pearson correlations for the variables included in the regression analysis revealed relationships with the dependent variable. I reviewed descriptive statistics to explore observed differences in multicultural competence scores between groups.

A standard regression analysis can be performed to (a) develop a regression equation in order to make predictions, (b) see how much variance in the dependent variable is accounted for by the independent variables, (c) identify which factors are significant predictors of the dependent variable, and (d) to examine the relative importance of the independent variables. There are five assumptions associated with multiple regression and include: (1) independence, (2) normally distributed errors, (3) linearity, (4) homoscedasticity, and (5) multicollinearity. When these assumptions are not met, a researcher is not able to draw accurate conclusions about reality. When assumptions are met, the regression model obtained from the sample can be accurately applied to the population of interest (Stevens, 2009). 
Finally, to answer research question four, a $2 \times 2$ between-subject analysis of variance (ANOVA) was performed. A two-way ANOVA is most often conducted if a researcher is interested in the combined interaction effect between independent variables. There are several advantages to conducting a two-way ANOVA, one of which is that more information can be gained from a two-way ANOVA compared to separate one-way ANOVAs. In a two-way ANOVA, the researcher is testing three hypotheses: (1) Main effect A, (2) Main effect B, and (3) the interaction between Main effect A and Main effect B. Conversely, one-way ANOVA does not account for the interaction effect between independent variables. Two-way ANOVA has three assumptions including independence, normality, and homogeneity of variance. The level of significance for all analyses was set at an alpha level of .05 .

RQ 1: Are there relationships between personal background characteristics (e.g., gender identity, race/ethnicity, engagement with populations different from one's own racial identity, highest degree completed by a parent/guardian, and sexual orientation) and multicultural competence score?

H1: The personal background characteristics racelethnicity, highest degree completed by a parent/guardian, and sexual orientation will have significantly positive, stronger correlations with multicultural competence score than other personal background characteristics.

RQ 2: Are there relationships between professional background characteristics (e.g., years of professional experience, academic degree level, and frequency of participation in multicultural coursework and training) and multicultural competence score? 
$\mathrm{H} 2$ : The characteristic frequency of participation in multicultural coursework and training will have a significantly positive, stronger correlation with multicultural competence score than other professional background characteristics.

RQ 3: Which background characteristics best predict multicultural competence score among participants?

H3: The background characteristics that will significantly predict multicultural competence score will be: sexual orientation, racelethnicity, and highest degree completed by a parent/guardian, along with engagement with populations different from one's own racial identity, and frequency of participation in multicultural coursework and training.

RQ 4: What are the combined effects of engagement with populations different from one's own racial identity and frequency of participation in multicultural coursework and training on multicultural competence score?

H4: There will be a significant interaction effect of engagement with populations different from one's own racial identity and frequency of participation in multicultural coursework and training on multicultural competence score.

\section{Role of the Researcher}

Among my many identities, I bring attention to my identities as an AfricanAmerican, heterosexual, cis female who has advised at mid-sized, public four-year predominantly White institutions for over a decade. ${ }^{2}$ My primary responsibilities in my role as an academic advisor included advising undergraduate students and developing professional development opportunities for advising professionals intended to increase

\footnotetext{
${ }^{2}$ Cis female refers to an individual's experience of their own gender matching the sex they were assigned at birth.
} 
levels of multicultural competence. The intersection of these identities and my experiences with mostly White students and White academic advisors may influence the ways in which I interpret the outcomes of my study. Assessing the multicultural competence of advising professionals, current and recent doctoral students, and current and recent master's students in the College Student Personnel program may assist advising professionals with the skills and strategies that can be universally applicable and beneficial to different student populations at different institutions.

\section{Limitations}

There are some limitations to consider when interpreting the results of this study presented in Chapter 4. Limitations are as follows:

1. The items in the MCSA-P2 focused primarily on issues of race instead of other cultural identities.

2. The descriptive study was limited to participant's self-reported perceptions of their multicultural competence.

3. Individual results were based on a volunteer sample and do not necessarily define the population to which the individuals belong.

4. The study was limited to undergraduate advising professionals and did not include undergraduate or graduate faculty advisors.

5. The target population for this study was relatively small, therefore affecting the sample size and the accurate cross-validation of results to the population of interest. 
6. The study was limited to a small sample, which affected the sizes of the independent variable category splits, the stability of the statistics, and ultimately the statistical power.

\section{Summary}

The purpose of this chapter was to provide a rationale for the methodological approach, to describe the research setting and sample, as well as to describe data collection and analysis techniques. I also detailed the development and validation of the Multicultural Competence in Student Affairs - Preliminary 2 (MCSA-P2) and explained my role as the researcher in the planning and conducting of this study. The following chapter presents the results of this study. 


\section{CHAPTER IV}

\section{RESULTS}

As stated in Chapter 1, the current study examined the relationship between key variables, both personal and professional characteristics, as they relate to multicultural competence. Four research questions and their corresponding directional hypotheses were introduced, and details about the methodology employed to test these hypotheses were discussed in Chapter 3. This chapter contains the sample demographics followed by the results based on the analyses for each research question described.

\section{Sample Demographics}

The overall sample for this study consisted of 81 participants (50\% response rate) who identified as an academic advising professional, a current master's or doctoral student in a counseling and personnel services program, and/or a recent master's or doctoral graduate of the same program. The sample comprised of 12 males (14.8\%), 68 females $(84.0 \%)$, and one participant chose not to identify a gender identity (1.2\%). With regard to race/ethnicity, the majority of the sample identified as White (76.5\%), followed by Black or African American (21.0\%), Hispanic or Latino/a (1.2\%), and those who preferred to not identify a race/ethnicity $(1.2 \%)$. Participants ranged in age from 23 years to 64 years, and the mean age was 33.4 years $(S D=9.13)$. Moreover, the sample included three individuals who identified as having a disability (3.7\%), 76 who identified as able-bodied (93.8\%), and two (2.5\%) who preferred to not identify an ability level. 
Additional sample characteristics revealed that $87.7 \%$ of the participants have traveled outside of the United States and 22.2\% have lived outside of the United States at one time. Finally, the majority of the sample identified as Christian (63.0\%) and Democrat $(55.6 \%)$.

In the current study sample, $23.5 \%$ identified as a member of a minority racial or ethnic group and $32.1 \%$ identified as a first-generation college student, indicating that these participants identified with an underrepresented group (Jones, 2013). Furthermore, $12.3 \%$ of the sample identified as a member of the lesbian, gay, bisexual, queer, or questioning community and $37 \%$ identified as a religious minority, indicating that these participants identified with a socially marginalized group (Mueller \& Pope, 2001).

Since the sample size in this study was small, and to reduce the possibility of making a Type I error, I reviewed frequency distributions of identifying characteristics to determine how to collapse and recode groups of my independent variables. For example, participants had the option of selecting one of five identities that best described their gender identity. After reviewing a frequency table and histogram, the distribution of responses for each identity could be best represented by two groups: "female" and "all other." Hence, the variable gender identity became a binary variable and was recoded to reflect this change. This same technique was applied to race/ethnicity ("White" and "All other") and sexual orientation ("Straight" and "All other") for analysis in the study.

Engagement with populations different from one's own racial identity and frequency of participation in multicultural coursework and training were recoded to reflect engagement or participation occurring monthly or more ("relatively frequent"), or semi-annually or less ("relatively rare") over the last three years. These two variables 
were then treated as categorical variables for the ANOVA. The variable years of professional experience was recoded to reflect 10 years or less ("relatively new") or 11 years or more ("relatively seasoned") of professional experience. Highest degree completed by a parent/guardian was collapsed to indicate completion of an associate's degree or higher (“College”), or high school diploma, technical, trade, or vocational training ("No college"). Finally, academic degree level was recoded and represented by two groups: "Advanced" (i.e., master's degree or higher) and "Undergraduate/other" (i.e., bachelor's degree or certification). See Table 8 for a breakdown of collapsed independent variables and Table 9 for general group characteristics.

Table 8

Collapsed Independent Variables

\begin{tabular}{|c|c|c|c|}
\hline Variable & Original Code & Cut-Off Point & Recoded Variable \\
\hline Gender Identity & $\begin{array}{l}1=\text { Male } \\
2=\text { Female } \\
3=\text { Non-binary } \\
4=\text { Not listed } \\
5=\text { I prefer not to answer }\end{array}$ & $\begin{array}{l}0=2 \\
1=1,3,4,5\end{array}$ & $\begin{array}{l}0=\text { Female } \\
1=\text { All other }\end{array}$ \\
\hline Race/Ethnicity & $\begin{array}{l}1=\text { Amer. Indian/Alaskan Native } \\
2=\text { Asian } \\
3=\text { Native Hawaiian or Pac. Isl. } \\
4=\text { Black or African American } \\
5=\text { Hispanic or Latino/a } \\
6=\text { Two or More Races } \\
7=\text { White } \\
8=\text { Not listed } \\
9=\text { I prefer not to answer }\end{array}$ & $\begin{array}{l}0=7 \\
1=1 \text { thru } 9\end{array}$ & $\begin{array}{l}0=\text { White } \\
1=\text { All other }\end{array}$ \\
\hline $\begin{array}{l}\text { Engagement } \\
\text { with Populations } \\
\text { Different from } \\
\text { Own Race }\end{array}$ & $\begin{array}{l}1=\text { Once } \\
2=\text { Daily } \\
3=\text { Weekly } \\
4=\text { Monthly } \\
5=\text { Semi-annually } \\
6=\text { Annually }\end{array}$ & $\begin{array}{l}0=2 \text { thru } 4 \\
1=1,5,6\end{array}$ & $\begin{array}{l}0=\text { Relatively } \\
\text { frequent; } \\
1=\text { Relatively rare }\end{array}$ \\
\hline
\end{tabular}

(Continued) 
Table 8 Continued.

\begin{tabular}{|c|c|c|c|}
\hline Variable & Original Code & Cut-Off Point & Recoded Variable \\
\hline $\begin{array}{l}\text { Highest Degree } \\
\text { Completed by a } \\
\text { Parent/Guardian }\end{array}$ & $\begin{array}{l}1=\text { HS diploma or equivalent } \\
2=\text { Technical, trade, or } \\
\text { vocational training } \\
3=\text { Associate's degree } \\
4=\text { Bachelor's degree } \\
5=\text { Master's degree } \\
6=\text { Doctor's degree } \\
7=\text { Professional degree } \\
8=\text { Not listed }\end{array}$ & $\begin{array}{l}0=3 \text { thru } 7 \\
1=1,2,8\end{array}$ & $\begin{array}{l}0=\text { College } \\
1=\text { No college }\end{array}$ \\
\hline $\begin{array}{l}\text { Sexual } \\
\text { Orientation }\end{array}$ & $\begin{array}{l}1=\text { Lesbian } \\
2=\text { Gay } \\
3=\text { Bisexual } \\
4=\text { Queer } \\
5=\text { Questioning } \\
6=\text { Straight } \\
7=\text { Not listed } \\
8=\text { I prefer not to answer }\end{array}$ & $\begin{array}{l}0=6 \\
1=1 \text { thru } 5,7,8\end{array}$ & $\begin{array}{l}0=\text { Straight } \\
1=\text { All other }\end{array}$ \\
\hline $\begin{array}{l}\text { Years of } \\
\text { Professional } \\
\text { Experience }\end{array}$ & Range $=1$ to 30 years & $\begin{array}{l}0=10 \text { yrs or less } \\
1=11 \text { yrs or more }\end{array}$ & $\begin{array}{l}0=\text { Relatively } \\
\text { new; } \\
1=\text { Relatively } \\
\text { seasoned }\end{array}$ \\
\hline $\begin{array}{l}\text { Academic } \\
\text { Degree Level }\end{array}$ & $\begin{array}{l}1=\text { HS diploma or equivalent } \\
2=\text { Technical, trade, or } \\
\text { vocational training } \\
3=\text { Associate's degree } \\
4=\text { Bachelor's degree } \\
5=\text { Master's degree } \\
6=\text { Doctor's degree } \\
7=\text { Professional degree } \\
8=\text { Not listed }\end{array}$ & $\begin{array}{l}0=5 \text { thru } 7 \\
1=1 \text { thru } 4,8\end{array}$ & $\begin{array}{l}0= \\
\text { Advanced degree; } \\
1= \\
\text { Undergrad/other }\end{array}$ \\
\hline $\begin{array}{l}\text { Frequency of } \\
\text { Multicultural } \\
\text { Training }\end{array}$ & $\begin{array}{l}1=\text { Once } \\
2=\text { Daily } \\
3=\text { Weekly } \\
4=\text { Monthly } \\
5=\text { Semi-annually } \\
6=\text { Annually }\end{array}$ & $\begin{array}{l}0=2 \text { thru } 4 ; \\
1=1,5,6\end{array}$ & $\begin{array}{l}0=\text { Relatively } \\
\text { frequent; } \\
1=\text { Relatively rare }\end{array}$ \\
\hline
\end{tabular}


Table 9

General Group Characteristics

\begin{tabular}{|c|c|c|}
\hline Variable & $N$ & $\%(n=81)$ \\
\hline \multicolumn{3}{|l|}{ Gender Identity } \\
\hline Female & 68 & $84.0 \%$ \\
\hline All other & 13 & $16.0 \%$ \\
\hline \multicolumn{3}{|l|}{ Race/Ethnicity } \\
\hline White & 62 & $76.5 \%$ \\
\hline All other & 19 & $23.5 \%$ \\
\hline \multicolumn{3}{|c|}{$\begin{array}{l}\text { Engagement with Populations Different } \\
\text { from Own Race }\end{array}$} \\
\hline Relatively frequent & 74 & $91.4 \%$ \\
\hline Relatively rare & 7 & $8.6 \%$ \\
\hline \multicolumn{3}{|c|}{ Degree Completed by a Parent/Guardian } \\
\hline College & 55 & $67.9 \%$ \\
\hline No college & 26 & $32.1 \%$ \\
\hline \multicolumn{3}{|l|}{ Sexual Orientation } \\
\hline Straight & 71 & $87.7 \%$ \\
\hline All Other & 10 & $12.3 \%$ \\
\hline \multicolumn{3}{|c|}{ Years of Professional Experience } \\
\hline Relatively new & 63 & $77.8 \%$ \\
\hline Relatively seasoned & 18 & $22.2 \%$ \\
\hline \multicolumn{3}{|l|}{ Academic Degree Level } \\
\hline Advanced degree & 71 & $87.7 \%$ \\
\hline Undergrad/other & 10 & $12.3 \%$ \\
\hline \multicolumn{3}{|c|}{ Frequency of Multicultural Training } \\
\hline Relatively frequent & 26 & $33.3 \%$ \\
\hline Relatively rare & 52 & $66.7 \%$ \\
\hline
\end{tabular}

*Note: Frequency of Multicultural Training was based on $n=78$

\section{Results}

Analyses focused on the relationships between personal and professional advisor attributes and multicultural competence score. In the following section, I reintroduce each research question and corresponding directional hypotheses, describe the analytic technique used to answer each research question, and present the respective results. 
RQ 1: Are there relationships between personal background characteristics (e.g., gender identity, race/ethnicity, engagement with populations different from one's own racial identity, highest degree completed by a parent/guardian, and sexual orientation) and multicultural competence score?

H1: The personal background characteristics racelethnicity, highest degree completed by a parent/guardian, and sexual orientation will have significantly positive, stronger correlations with multicultural competence score than other personal background characteristics.

RQ 2. Are there relationships between professional background characteristics (e.g., years of professional experience, academic degree level, and frequency of participation in multicultural coursework and training) and multicultural competence score?

$\mathrm{H} 2$ : The characteristic frequency of participation in multicultural coursework and training will have a significantly positive, stronger correlation with multicultural competence score than other professional background characteristics.

A standard regression analysis was performed between the dependent variable (multicultural competence score) and the independent variables (gender identity, racelethnicity, engagement with populations different from one's own racial identity, highest degree completed by a parent/guardian, sexual orientation, years of professional experience, academic degree level, and frequency of participation in multicultural coursework and training). Analyses show that 80 cases were included and the mean multicultural competence score for this sample was $179.88(S D=32.47)$. Assumptions were tested by examining the histogram of residuals and the plot of studentized residuals 
by standardized predicted values. The correlation matrix was also examined for multicollinearity. No serious violations of independence, normality, linearity, homoscedasticity, or multicollinearity were detected. However, there was evidence of a possible outlier. The maximum value for the Centered Leverage Value was .386 and this statistic exceeds the threshold value for these data which was .34. However, no cases exceed the Cook's Distance value (> 1.00) that indicates that a case is influential. Correlations shown in Table 10 indicate that two predictors were significantly $(p<.05)$ related to the dependent variable (see Appendix D).

I chose the simultaneous entry method, with all eight variables entering the regression equation. The overall significance test of the equation is significant at the .05 alpha level, $F(8,71)=2.518, p<.05$ and is displayed in Table 11. There were relationships between the independent variables and multicultural competence in the population from which the sample was drawn. $R^{2}$ for the regression equation was .221 . However, adjusted $R^{2}$ (using the Wherry formula) was .133, indicating that approximately $13.3 \%$ of the variance in multicultural competence score would have been accounted for if the regression equation had been derived from the population from which the sample was drawn.

Table 11

Multicultural Competence ANOVA Summary Table for Regression

\begin{tabular}{lcccc}
\hline \multicolumn{1}{c}{ Source } & SS & DF & MS & $F$ \\
\hline Regression & 18403.408 & 8 & 2300.426 & 2.518 \\
Residual & 64867.342 & 71 & 913.625 & \\
Total & 83270.750 & 79 & & \\
\hline Note: Computed using alpha $=.05$ & & & &
\end{tabular}


The hypothesis for research question one was partially supported by the results in this study. Results of the standard regression analysis indicated that only the personal background characteristic racelethnicity had a significantly positive, moderate relationship with multicultural competence score $(\beta=.222, p<.05)$. Based on the standardized coefficient, the personal background characteristic highest degree completed by a parent/guardian $(\beta=-.085, p>.05)$ had a weak, inverse relationship with the dependent variable. Sexual orientation $(\beta=.075, p>.05)$ also had a weak association with multicultural competence score and neither of these personal background attributes had statistically significant relationships with the dependent variable.

The professional background characteristic frequency of participation in multicultural coursework and training was found to have a significantly moderate, inverse relationship with multicultural competence score $(\beta=-.378, p<.05)$. However, since this variable was recoded $(0=$ Relatively frequent, $1=$ Relatively rare $)$, the linear relationship can be described as the less frequent one's participation with multicultural coursework and training, the lower one's multicultural competence score. Thus, the hypothesis for research question two was upheld.

RQ 3. Which background characteristics best predict multicultural competence score among participants?

H3: The background characteristics that will significantly predict multicultural competence score will be: sexual orientation, racelethnicity, and highest degree completed by a parent/guardian, along with engagement with populations different from one's own racial identity, and frequency of participation in multicultural coursework and training. 
Results of the regression model revealed that the background characteristics that best predicted multicultural competence score, listed in order from strongest to weakest associations, were multicultural coursework and training $(t=-3.191, p<.05)$, and race/ethnicity $(t=2.010, p<.05)$. Both predictors had relatively moderate associations with multicultural competence score. While these two characteristics best predicted multicultural competence score, the hypothesis for research question three was not supported by the results because not all variables included in the hypothesis had statistically significant relationships with multicultural competence score. Refer to Table 12 for a list of the regression coefficients, $t$ values, and values of significance test.

Table 12

Regression Coefficients and Results of Significance Test

\begin{tabular}{lcccc}
\hline \multicolumn{1}{c}{ Variables } & $\begin{array}{c}\text { Unstandardized } \\
\text { Coefficients }\end{array}$ & $\begin{array}{c}\text { Standardized } \\
\text { Coefficients }\end{array}$ & $t$ value & Significance \\
\hline (Constant) & 191.238 & & 24.741 & .000 \\
Race/Ethnicity & 16.835 & .222 & 2.010 & $.048^{*}$ \\
Engagement & 12.668 & .111 & 1.004 & .319 \\
Parent Degree & -5.821 & -.085 & -.762 & .449 \\
Professional Years & 16.384 & .208 & 1.790 & .078 \\
Education Level & -9.134 & -.089 & -.817 & .417 \\
MCC Training & -26.041 & -.378 & -3.191 & $.002^{*}$ \\
Gender Identity & -2.286 & -.026 & -.244 & .808 \\
Sexual Orientation & 7.335 & .075 & .668 & .507 \\
\hline
\end{tabular}

Note: Dependent Variable: Multicultural Competence Score.

*Asterisk indicates statistical significance at .05 alpha level.

RQ 4: What are the combined effects of engagement with populations different from one's own racial identity and frequency of participation in multicultural coursework and training on multicultural competence score? 
H4: There will be a significant interaction effect of engagement with populations different from one's own racial identity and frequency of participation in multicultural coursework and training on multicultural competence score.

While a $2 \times 2$ between subject analysis of variance (ANOVA) was planned, it could not be carried out due to the fact that no participants fell into one of the categories (i.e., "relatively frequent MCC training" by "relatively rare" engagement category). Therefore, research question four could not be addressed in this study.

\section{Summary}

Chapter four began with an introduction of the sample demographics. The sample was comprised of 81 participants who identified as an academic advising professional, a current master's or doctoral student in a counseling and personnel services program, and/or a recent master's or doctoral graduate of the same program. The sample consisted of 12 males (14.8\%), 68 females (84.0\%), and one participant chose not to identify a gender identity $(1.2 \%)$. With regard to race/ethnicity, the majority of the sample identified as White (76.5\%), followed by Black or African American (21.0\%), Hispanic or Latino/a (1.2\%), and those who preferred to not identify a race/ethnicity $(1.2 \%)$. Participants ranged in age from 23 years to 64 years, and the mean age was 33.4 years $(S D=9.13)$. The average multicultural competence score for the sample was 179.37.

The four research questions, their respective hypotheses, and the methodology employed to test these hypotheses were discussed. Data were analyzed using SPSS 22.0 and results for each question were provided. The significance level was set at an alpha level of .05. Table 13 provides a summary of the results. 
Table 13

\section{Summary of Results}

Research Question

1. Are there relationships between personal background characteristics and multicultural competence score?

2. Are there relationships between professional background characteristics and multicultural competence score?

3. Which background characteristics best predict multicultural competence score?

4. What are the combined effects of engagement with populations different from one's own racial identity and frequency of participation with multicultural coursework and training on multicultural competence score?
Statistical Procedure

Standard Regression

Standard Regression

Standard Regression

2-Way ANOVA

Analysis could not be performed. Hypothesis was not tested.

Race/ethnicity was significantly associated with multicultural competence score. Hypothesis was partially supported.

Frequency of participation in multicultural coursework and training was significantly associated with multicultural competence score. Hypothesis was supported.

Frequency of participation in multicultural coursework and training and race/ethnicity best predict multicultural competence score. Hypothesis was not supported.

performed. Hypothesis was




\section{CHAPTER V \\ DISCUSSION AND CONCLUSIONS}

The intent of this dissertation study was to identify and examine relationships between personal and professional background characteristics and multicultural competence score among academic advising professionals and current and recent master's and doctoral students in a counseling and personnel services preparation program. Multicultural competence in this study was defined as "the awareness, knowledge, and skills needed to work with others who are culturally different from self in meaningful, relevant, and productive ways" (Pope, Reynolds, \& Mueller, 2004, p. 13). Data obtained from the sample were analyzed for three of the four research questions in the study, and the results were presented in Chapter 4. This final chapter will discuss the results in further detail and describe their relevance to existing research. Implications for future research and practice will also be addressed.

Chapters 1 and 2 showed the call made to postsecondary education to generate a more educated, socially just citizenry. These chapters also discussed the ethical responsibility academic advising professionals have to advise all students equitably, and how, through the application of these equitable practices, academic advisors can assist with degree completion among students of color. Past research revealed that academic advisors and the skills they use in practice have a significant impact on the students they advise. It is evident from the advising literature that multicultural competence is essential when advising students with cultures similar to and different from one's own (Cornett- 
DeVito \& Reeves, 1998; Fox, 2008; Museus \& Ravello, 2010; Shaffer, 1998; Shultz et. al, 2001; Tan, 1995). Ethical, effective academic advising requires that advisors recognize cultural differences and perceived power differences, uphold pre-college cultural affiliations and traditions, empathize with students, and advocate on behalf of students.

Gaps in the research revealed that studies (a) did not examine attitudes, sets of skills, and knowledge academic advisors have in relation to supporting students of color; (b) did not explore the degree to which an advising professional's background characteristics affect cultural biases, values and worldviews, and/or (c) did not include or report on samples of racially/ethnically diverse advising professionals in geographic regions of the United States with racially/ethnically diverse community populations. This demonstrated that there is a clear and urgent need to examine multicultural competence among academic advising professionals in an urban setting.

\section{Discussion}

While the majority of the sample in this study identified as White $(76.5 \%)$, female (84.0\%), Straight (87.7\%), Christian (63.0\%), able-bodied (93.8\%), and having an advanced degree $(88.8 \%)$, the participants seemed to offer new information not aligned with research in the field. For instance, $87.7 \%$ of the participants had traveled outside of the United States and $22.0 \%$ had lived outside of the United States at one time. This suggests that a large majority of the current sample had an awareness of and experiences with cultures other than the American culture. In addition, $91.4 \%$ of the sample indicated that over the last three years they engaged with populations of a racial identity different from their own racial identity on a monthly basis or more frequently. This was a 
noteworthy characteristic since $67.9 \%$ of the sample also indicated that over the same time period, they participated in multicultural coursework or training semi-annually or less frequently. This suggested that while the current sample in this study frequently engaged with others of racially/ethnically diverse backgrounds, they did not attend multicultural coursework or training as frequently.

The regression analysis revealed that all eight personal and professional background characteristics significantly predicted multicultural competence score. The adjusted $R^{2}$ (using the Wherry formula) for the regression model was .133, indicating that approximately $13.3 \%$ of the variance in multicultural competence score would have been accounted for if the regression equation had been derived from the population from which the sample was drawn. This also meant that $86.7 \%$ of the variance in multicultural competence score would not have been accounted for if the regression equation had been derived from the same population. As cited in the extant literature, multicultural awareness, knowledge, skills, and respect are competencies for good student affairs and culturally competent advising practice (Harding, 2008; Pope \& Reynolds, 1997). The results of this analysis accentuated the serious need to better understand what personal and professional background attributes are connected to higher multicultural competence scores and, further, how one can improve their multicultural competence score.

As acknowledged in the limitations presented in Chapter 3, results obtained from the small sample size in this study would affect the generalizability of the regression model to the target population, therefore making it difficult to predict values of multicultural competence score when the regression model is applied to different samples from the same population. The findings in this study pointed to the possibility that a 
larger sample size would better support accurate generalizations about the relationships between personal and professional background characteristics and multicultural competence score among academic advising professionals at a large, urban, research institution in the southern United States. Additionally, increasing the sample size in a subsequent study may also prevent the need to collapse groups of independent variables, preserving unique participant data, so that differences in multicultural competence score between groups can be further examined.

The most important individual findings were that racelethnicity and frequency of participation in multicultural coursework and training best predicted multicultural competence score. No individual significant relationships were found between multicultural competence score and the personal background characteristics gender identity, engagement with populations different from one's own racial identity, highest degree completed by a parent/guardian, or sexual orientation. No individual significant relationships were found between multicultural competence score and the professional background characteristics years of professional experience or academic degree level.

To that end, there was evidence to support that further analysis is needed to determine if participants who identified with an underrepresented group will have significantly positive, stronger correlations with multicultural competence score than participants who did not. Although there was a significantly positive relationship between the personal background characteristic racelethnicity and multicultural competence score $(t=2.010, p<.05)$, it was a moderate relationship, and where the difference lies in multicultural competence score between racial/ethnic groups is not determined. Moreover, since the personal background characteristics highest degree 
completed by a parent/guardian and sexual orientation were not found to have a significant relationship with the multicultural competence score, no additional analyses were necessary to determine if there were differences in multicultural competence score between participants who identified as first-generation college students (i.e., identified with an underrepresented group) and those who were not, as well as participants who identified as lesbian, gay, bisexual, queer, or questioning (i.e., identified with a socially marginalized group) and participants who identified as straight.

Chapter 3 cited research on the MCSA-P2, and results from previous studies indicated that certain variables such as race, participation with diversity training (Porter, 2011), and/or experience with training of multicultural programs or identification with a socially marginalized group (Mueller \& Pope, 2001) were related to multicultural competence. Findings from the current study maintained that the variables race/ethnicity and participation in diversity training, in particular, were significantly related to multicultural competence score. Findings from this study did not support previous conclusions that participants who identified with a socially marginalized group (e.g., lesbian, gay, bisexual, queer, or questioning community, and/or religious minorities) were significantly associated with multicultural competence, or at least on a measure of multicultural competence that mainly addresses race. Factors that contributed to this finding included (a) the background characteristic sexual orientation was not found to be a significant predictor of multicultural competence score, (b) religious affiliation was not included as a background characteristic for analysis in this study, and (c) an analysis to determine group differences in multicultural competence score was not performed. 
Results from research question three indicated that frequency of participation in multicultural coursework and training and racelethnicity best predicted multicultural competence score. It is important to restate that frequency of participation in multicultural coursework and training had a moderate, inverse relationship with multicultural competence score. Since this variable was recoded $(0=$ Relatively frequent, $1=$ Relatively rare), the linear relationship can be described as the less frequent one's participation with multicultural coursework and training, the lower one's multicultural competence score.

To describe a multiculturally competent advisor as Reynolds and Pope (2003) and Harding (2008) have advocated, academic advising professionals must be educated about underrepresented groups to have the ability to build culturally responsive relationships with these students (Cunningham, 2003; Gilbert, 2005; Harding 2012). Enrolling in multicultural coursework or participating in multicultural training is one way to be formally educated about diverse populations, and may better inform academic advising professionals about structural and systemic forms of oppression that contribute to the biculturalism and dual socialization many students of color experience, as previously discussed by Rendón et al. (2000). Formal instruction offered in a multicultural course or training may provide a space in which academic advising professionals can better understand and analyze beliefs, norms, assumptions, and practices that give meaning to their world, more so than informal exchanges with peers or family members. By considering how the social context affects not only their understanding of education, but that of students' too, academic advisors could lay the foundation for how to help students 
of color navigate unknown college norms early in their college careers (Hemwall \& Trachte, 2005) and prepare for global citizenship (Lowenstein, 2005).

Similarly, and based on Paris' (2012) concept of culturally sustaining pedagogy, formal instruction about deficit approaches and the existing social order offered in a multicultural course or training could encourage academic advisors to facilitate a student of color's learning about their cultural identities and those around them so as not to promote the disassociation of their pre-college affiliations. As previously noted, Tinto's model provides a framework to broadly understand the early student departure process, but struggles to describe the departure process for different student groups of color (Rendón et al., 2000). In response to this disparity, the conceptual framework offered in this study can guide academic advisors in the exploration of their selves, their students, and their practice to better increase degree completion among students of color.

\section{Recommendations for Research}

As with any study, limitations did not allow for as thorough a study as possible, leaving much to be considered for continued research. First, since a large proportion of the variance in multicultural competence score was not accounted for by the variables in the current study, it would be sensible to assess the personal and professional background characteristics academic advising professionals perceive to be significant when working with students. These characteristics can be informed by the extant advising literature, as well as academic advising professionals' experiences. Second, it would be paramount to conduct a study similar to this one across several different institution types and in different geographic regions of the country using the newly generated background characteristics. Data from a substantially larger, explicitly defined target population, 
analyzed using multivariate and multi-level techniques, could provide more insight into (a) which background characteristics best predict multicultural competence score, (b) which individual background characteristics significantly predict values of multicultural competence score, and (c) how much variance in multicultural competence score is accounted for by background characteristics. Third, further analysis is necessary to observe differences in main effects and interaction effects of background characteristics on multicultural competence score. Not only is looking at how the interaction of certain background characteristics contributing to multicultural competence score realistic, the more variability in multicultural competence score is controlled, the more error variance is precisely estimated and the more generalizable the results would be to the target population. Fourth, although race/ethnicity was a significant predictor of multicultural competence score in the current study, further analysis was needed to identify the differences, if any, in multicultural competence score between racial/ethnic groups.

Next, given that the amount of engagement with populations different from one's own racial identity was not a significant predictor of multicultural competence score, it seems fitting to consider if the kinds of exchanges one has with an individual different from one's own racial identity, and/or what happens during these kinds of exchanges, is a significant predictor of multicultural competence score. Extending this line of research further, a future study could examine the association between multicultural competence score and the kind of multicultural coursework and training individuals participate in. Does the quality of the multicultural coursework and training affect multicultural competence score? 
Sixth, one of the limitations identified in the current study was that the items of the MCSA-P2 focused exclusively on issues of race and not multiple cultural identities. Future research could consider how academic advising professionals define the term multicultural competence, and an instrument could be developed that more accurately reflects items that are inclusive of race and multiple cultural identities. Continuing with this line of inquiry, it would be interesting to explore how the current socio-political context shapes items included in such an instrument, and how such a context affects exchanges with others who are culturally different from one's self. Is multicultural competence an outcome, a mediating variable used to measure an outcome, or both?

Seventh, additional studies could seek to identify the successes and challenges that academic advising professionals, students, and faculty in a counseling and personnel services preparation program experience related to multicultural competence. This information may reveal issues related to multicultural competence such as privilege, guilt, and the desirability to work with others who are culturally different from one's self (Pope, Reynolds, \& Mueller, 2004).

Subsequent studies conducted could also consider how the content and materials included in multicultural courses offered in counseling and personnel services preparation programs influence multicultural competence scores among academic advising professionals. This may include employing both qualitative and quantitative approaches with a mixed sample of both academic advising professionals and students.

And finally, since the self-assessment was partially based on a volunteer sample of professional academic advisors, it is essential that student perceptions of multicultural competence among both professional and faculty advisors also be examined. Results 
from a study about students' perceptions of multicultural competence among professional and faculty advisors may more accurately describe the nature of academic advising, areas for improvement in practice, and future directions for research.

\section{Recommendations for Practice}

While this study has shown the importance race/ethnicity and relatively frequent participation in multicultural coursework and training has on multicultural competence score, it has similarly shown that future research about multicultural competence is critical to strengthening our understanding, as practitioners, of what our responsibility is to advising all students equitably. In this regard, the extent to which campuses are examining the experiences academic advising professionals have with socially marginalized and underrepresented students remains an essential vehicle to enhance academic advising competences. Some suggestions for future practice are offered in Table 14, and are organized into three groups: the global/national level, the institutional level, and the individual level. 
Table 14

Recommendations for Professional Preparation, Faculty, or Curricula Future Practice

\begin{tabular}{lll}
\hline \multicolumn{1}{c}{ Level } & \multicolumn{1}{c}{ Topic } & \multicolumn{1}{c}{ Recommendation } \\
\hline $\begin{array}{l}\text { Global/National } \\
\text { (e.g., NACADA, ACPA NASPA) }\end{array}$ & 1. Orientation for new advisors & $\begin{array}{l}\text { Introduce and emphasize ethical } \\
\text { responsibility to advise all students } \\
\text { equitably (globally and nationally) }\end{array}$ \\
& 2. Models/theories of multicultural \\
competence & $\begin{array}{l}\text { Identify and make models/theories of } \\
\text { multicultural competence readily } \\
\text { available for professional community }\end{array}$
\end{tabular}

3. Language and key terms

Discuss culturally sensitive language and key terms used to describe populations at the global/national level

4. Skills and competencies

Demonstrate effective and normed skills and competencies that promote equitable advising practice

\section{Institutional}

(i.e., based on institutional type)
1. Orientation for new advisors
Introduce and emphasize ethical responsibility to advise all students equitably

Share descriptive and inferential data between student groups on campus about retention rates, interactions with faculty, satisfaction with advising services, etc. 
Table 14 Continued.

\begin{tabular}{|c|c|c|}
\hline Level & Topic & Recommendation \\
\hline \multirow[t]{3}{*}{ Institutional (continued) } & 2. Ongoing professional development & $\begin{array}{l}\text { Obtain and share baseline information } \\
\text { regarding academic advisors' } \\
\text { experiences in the field and in life with } \\
\text { cultures different from their own }\end{array}$ \\
\hline & & $\begin{array}{l}\text { Evaluate diversity } \\
\text { programs/multicultural coursework } \\
\text { offered or sponsored on campus }\end{array}$ \\
\hline & 3. Diversity, inclusion, and equity & $\begin{array}{l}\text { Learn about the goals and objectives for } \\
\text { diversity, inclusion, and equity on } \\
\text { campus, share with advising } \\
\text { community, and discuss role of } \\
\text { advising in meeting these goals and } \\
\text { objectives }\end{array}$ \\
\hline \multirow[t]{3}{*}{$\begin{array}{l}\text { Individual } \\
\text { (e.g., self) }\end{array}$} & 1. Assess multicultural competence & $\begin{array}{l}\text { Engage in critical self-reflection about } \\
\text { awareness, knowledge, and skills about } \\
\text { others who are culturally different }\end{array}$ \\
\hline & & $\begin{array}{l}\text { Actively participate in multicultural } \\
\text { programming and events sponsored on } \\
\text { campus or in the community }\end{array}$ \\
\hline & $\begin{array}{l}\text { 2. Identify challenges or concerns } \\
\text { related to working with others who } \\
\text { are culturally different }\end{array}$ & $\begin{array}{l}\text { Create professional development } \\
\text { communities to support the exchange of } \\
\text { concerns and ideas about developing } \\
\text { multicultural competence }\end{array}$ \\
\hline
\end{tabular}


Until this study, multicultural competence among academic advising professionals had not been empirically examined at this institution. It would be valuable to present and discuss the findings of this study to the academic advising community, and the faculty and students in the counseling and personnel services preparation program at this institution. Feedback from this community may guide directions for future research and practice at the individual, institutional, national, and global levels. Results from this study provided evidence that the frequency of participation in multicultural coursework or training is a significant predictor of multicultural competence scores. To this end, it would be advantageous to identify (a) the different types of trainings and multicultural courses the participants experienced, (b) the content and topics included in the trainings or courses, (c) how often these types of trainings or courses were offered, (d) the populations the trainings targeted, and (e) the level of satisfaction with these trainings or courses. This may help institutional practitioners and faculty determine what types of professional development opportunities need to be offered more regularly based on differentiated learning (e.g., trainings for new professionals and seasoned professionals, or more advanced coursework for students and professionals seeking advanced skills and competencies in their practice).

\section{Conclusion}

In an era in which the growing importance of completing a postsecondary degree has prompted academic advisors to examine their roles in the preparation of students, recent attention has been paid to the characteristics of academic advising that promote success among students of color. Within this research, however, it was unclear the degree to which an academic advisor's personal and professional background affects 
those characteristics. Research contends there is an urgent need to examine multicultural competence in the context of effective advising skills. Undergirding these skills is the explicit ethical responsibility academic advisors have to advise all students equitably.

To better understand the relationship between personal and professional background attributes and multicultural competence, a survey study was conducted at a large, public, urban research institution in the southern United States. Findings suggested that an advising professional's race/ethnicity and frequency of participation in multicultural coursework and training were significant predictors of multicultural competence scores. These results support findings from previous studies using the MCSA-P2.

Ultimately, the responsibility for increased efficacy of advising practice lies within both the scholarly work of researchers and the clinical work of practitioners. In order to serve all students, their institutions, and the community rightfully, multicultural competence and its relation to academic advising must be at the forefront of future research. 


\section{REFERENCES}

Astin, A. W. (1992). Minorities in American higher education. San Francisco, CA: Jossey-Bass.

Bloom, J. L., Cuevas, A. E. P., Hall, J. W., \& Evans, C. V. (2007). Graduate students' perceptions of outstanding graduate advisor characteristics. NACADA Journal, 27, 28-35.

Brown, T., \& Rivas, M. (1993). Advising multicultural populations for achievement and success. New Directions for Community Colleges, 82, 83-96.

Cabrera, A. F., Nora, A., Terenzini, P. T., Pascarella, E., \& Hagedorn, L. (1999). Campus racial climate and the adjustment of students to college: A comparison between white students and African-American students. Journal of Higher Education, 70, 134-160.

Carter, D. F. (2006). Key issues in the persistence of underrepresented minority students. New Directions for Institutional Research, 130, 33-46.

Castellanos, J., Gloria, A. M., Mayorga, M., \& Salas, C. (2007). Student affairs professionals' self-report of multicultural competence: Understanding awareness, knowledge, and skills. NASPA Journal, 44(4), 643-663.

Clark, E., \& Kalionzes, J. (2008). Advising students of color and international students. In V. Gordon, W. Habley, \& T. Grites and Associates (Eds.), Academic advising: A comprehensive handbook (pp. 204-226). San Francisco, CA: Jossey-Bass. 
Coll, J. E. (2009). A study of academic advising satisfaction and its relationship to student worldviews. Journal of College Student Retention, 10(3), 391-404.

Cornett-DeVito, M. M., \& Reeves, K. J. (1999). Preparing students for success in a multicultural world: faculty advisement and intercultural communication. NACADA Journal, 19(1), 35-44.

Crookston, B. B. (1972). A developmental view of academic advising as teaching. Journal of College Student Personnel, 13, 12-17.

Cunningham, L. A. (2003). Multicultural awareness. Retrieved from the NACADA Clearinghouse of Academic Advising Resources Web site: http://www.nacada.ksu.edu/Resources/Clearinghouse/ViewArticles/Multicultural-a84.aspx

Cuyjet, M. J. (2011). Environmental influences on college culture. In M. Cuyjet, M. Howard-Hamilton, \& D. Cooper (Eds.), Multiculturalism on campus: Theory, models, and practices for understanding diversity and creating inclusion (pp. 3763). Sterling, VA: Stylus Publishing.

Dillman, D. A., Smyth, J. D., Christian, L. M., \& Dillman, D. A. (2009). Internet, mail, and mixed-mode surveys: The tailored design method. Hoboken, NJ: Wiley \& Sons.

Dumas, T. N. (2014). Characteristics of academic advising skills related to student satisfaction: A meta-analytic review. Unpublished manuscript.

Durkheim, E. (1951). Suicide: A study in sociology. Glencoe, IL: Free Press. 
Ebbers, L. H., \& Henry, S. L. (1990). Cultural competence: A new challenge to student affairs professionals. NASPA Journal, 27, 319-323.

Fiddler, M. B., \& Alicea, M. (1996). Use of a collective narrative process to articulate practice-based advising competencies. NACADA Journal, 16(1), 14-20.

Fischer, M. J. (2007). Settling into campus life: differences by race/ethnicity in college involvement and outcomes. Journal of Higher Education, 78, 125-161.

Fox, R. (2008). Delivering one-to-one advising: Skills and competencies. In V. Gordon, W. Habley, \& T. Grites and Associates (Eds.), Academic advising: A comprehensive handbook (pp. 342-355). San Francisco, CA: Jossey-Bass.

Franklin-Craft, A. (2010). An assessment of intercultural competence of student affairs administrators (Doctoral dissertation). Retrieved from ERIC (ED522112.).

Freire, P. (1970). Pedagogy of the oppressed. New York, NY: Herder and Herder.

Gilbert, C. (2005). Improving academic advisor preparation through cultural awareness. Academic Advising Today, 28(3). Retrieved from http://www.nacada.ksu.edu/Resources/Academic-Advising-Today/ViewArticles/Improving-Academic-Advisor-Preparation-Through-Cultural-SelfAwareness.aspx

Gillispie, B. (2003). History of academic advising. Retrieved from NACADA Clearinghouse of Academic Advising Resources Web site: http://www.nacada.ksu.edu/Resources/Clearinghouse/View-Articles/History-ofacademic-advising.aspx 
Grites, T. (2013). Developmental academic advising: A 40-year context. NACADA Journal, 33(1), 5-15.

Grites, T. J., Gordon, V. N., Habley, W. R., (2008). Perspectives on the future of academic advising. In V. Gordon, W. Habley, T. Grites, and Associates (Eds.), Academic advising: A comprehensive handbook (pp. 456-472). San Francisco, CA: Jossey-Bass.

Guiffrida, D. (2006). Toward a cultural advancement of Tinto's theory. The Review of Higher Education, 29, 451-472.

Hagedorn, L. S. (2005). How to define retention: A new look at an old problem. In A. Seidman (Ed.), College student retention: Formula for student success (pp. 89105). Westport, CT: Praeger Publishers.

Hagen, P. L., \& Jordan, P. (2008). Theoretical foundations of academic advising. In V. Gordon, W. Habley, T. Grites, and Associates (Eds.), Academic advising: A comprehensive handbook (pp. 17-35). San Francisco, CA: Jossey-Bass.

Harding, B. (2008). Students with specific advising needs. In V. Gordon, W. Habley, T. Grites, and Associates (Eds.), Academic advising: A comprehensive handbook (pp. 189-203). San Francisco, CA: Jossey-Bass.

Harding, B. (2012). Students of color. Retrieved from the NACADA Clearinghouse of Academic Advising Resources Web site: http://www.nacada.ksu.edu/Resources/Clearinghouse/View-Articles/Advisingstudents-of-color.aspx 
Harrison, E. (2009). What constitutes good academic advising? Nursing students' perceptions of academic advising. Journal of Nursing Education, 48, 361-366.

Hemwall, M. K. (2008). Advising delivery: Faculty advising. In V. Gordon, W. Habley, T. Grites, and Associates (Eds.), Academic advising: A comprehensive handbook (pp. 253-266). San Francisco, CA: Jossey-Bass.

Hemwall, M. K., \& Trachte, K. C. (1999). Learning at the core: Toward a new understanding of academic advising. NACADA Journal, 19(1), 5-11.

Hemwall, M. K., \& Trachte, K. C. (2005). Academic advising as learning: 10 organizing principles. NACADA Journal, 25(2), 74-83.

Hemwall, M., Trachte, K. C., \& National Academic Advising Association (U.S.). (2003). Advising and learning: Academic advising from the perspective of small colleges and universities. Manhattan, KS: NACADA (National Academic Advising Association).

Jones, A. P. (2013). Introduction: Improving postsecondary access, persistence, and completion in the United States: Setting the stage. In L. Perna and A. Jones (Eds.), The state of college access and completion: Improving college success for students from underrepresented groups (pp. 1-9). New York, NY: Routledge.

King, P. M., \& Howard-Hamilton, M. (2003). An assessment of multicultural competence. NASPA Journal, 40(2).

Kuh, G. D. (2008). Advising for student success. In V. Gordon, W. Habley, T. Grites, and Associates (Eds.), Academic advising: A comprehensive handbook (pp. 68-84). San Francisco, CA: Jossey-Bass. 
Kuhn, T. L. (2008). Historical foundations of academic advising. In V. Gordon, W. Habley, T. Grites, and Associates (Eds.), Academic advising: A comprehensive handbook (pp. 3-16). San Francisco, CA: Jossey-Bass.

Ladson-Billings, G. (1995). Toward a theory of culturally relevant pedagogy. American Educational Research Journal, 32, 465-491.

Lowenstein, M. (2005). If advising is teaching, what do advisors teach? NACADA Journal, 25(2), 65-73.

Lowenstein, M. (2008). Ethical foundations of academic advising. In V. Gordon, W. Habley, T. Grites, and Associates (Eds.), Academic advising: A comprehensive handbook (pp. 36-49). San Francisco, CA: Jossey-Bass.

Mueller, J. A., \& Pope, R. L. (2001). The relationship between multicultural competence and White racial consciousness among student affairs practitioners. Journal of College Student Development, 42, 133-144.

Museus, S. D., \& Ravello, J. N. (2010). Characteristics of academic advising that contribute to racial and ethnic minority student success at predominantly White institutions. NACADA Journal, 30(1), 47-58.

NACADA (1995). Subject index. Retrieved from the NACADA Journal Information Web site: http://www.nacada.ksu.edu/portals/0/Journal/documents/Subject-Index-152.pdf

NACADA. (2005). NACADA statement of core values of academic advising. Retrieved from the NACADA Clearinghouse of Academic Advising Resources Web site: 
http://www.nacada.ksu.edu/Resources/Clearinghouse/View-Articles/Core-valuesof-academic-advising.aspx

NACADA (2010). Cumulative subject index to volumes 16-30 of the NACADA journal.

Retrieved from the NACADA Journal Information Web site:

http://www.nacada.ksu.edu/portals/0/Journal/documents/Cumulative-Index-

Vol.16-30-accessible.pdf

National Survey of Student Engagement. (2013). A fresh look at student engagementAnnual results 2013. Bloomington, IN: Indiana University Center for Postsecondary Research.

O’Banion, T. (1972). An academic advising model. Junior College Journal, 42(6), 62-69.

Pardee, C. F. (2004).Organizational structures for advising. Retrieved from the NACADA Clearinghouse of Academic Advising Resources Web site: http://www.nacada.ksu.edu/Resources/Clearinghouse/ViewArticles/Organizational-Models-for-Advising.aspx

Paris, D. (2012). Culturally sustaining pedagogy: A needed change in stance, terminology, and practice. Educational Researcher, 41(3), 93-97.

Pope, R. L., \& Mueller, J. A., (2000). Development and initial validation of the multicultural competence in student affairs-preliminary 2 scale. Journal of College Student Development, 41, 599-608.

Pope, R. L., Mueller, J. A., \& Reynolds, A. L. (2009). Looking back and moving forward: Future directions for diversity research in student affairs. Journal of College Student Development, 50, 640-658. 
Pope, R. L., \& Reynolds, A. L. (1997). Student affairs core competencies: Integrating multicultural awareness, knowledge, and skills. Journal of College Student Development, 38, 266-277.

Pope, R. L., Reynolds, A. L., \& Mueller, J. A., (2004). Multicultural competence in student affairs. San Francisco, CA; Jossey-Bass.

Porter, P. L. (2011). Multicultural competence of student affairs administrators at member institutions of the Council for Christian Colleges and Universities (Doctoral dissertation). Retrieved from ERIC (ED540016.).

Rendón, L. I. (1994). Validating cultural diverse students: Toward a new model of learning and student development. Innovative Higher Education, 19(1), 3-51.

Rendón, L. I., Jalomo, R., \& Nora, A. (2000). Theoretical considerations in the study of minority student retention in higher education. In J. M. Braxton (Ed.), Reworking the student departure puzzle (pp. 127-156). Nashville, TN: Vanderbilt University Press.

Reynolds, A. L., \& Pope, R. L. (1994). Perspectives on creating multicultural campuses. Journal of American College Health, 42, 229-233.

Reynolds, A. L., \& Pope, R. L. (2003). Multicultural competence in college counseling centers. In D. B. Pope-Davis, H. L. K. Coleman, W. M. Liu, \& R. L. Toporek (Eds.), Handbook of multicultural competencies. Thousand Oaks, CA: Sage.

Rhatigan, J. J. (2009). From the people up: A brief history of student affairs administration. In McClellan, G. S., \& Stringer, J. (Eds.), The handbook of student affairs administration (pp. 3-18). San Francisco, CA: Jossey Bass. 
Self, C. (2008). Advising delivery: Professional advisors, counselors, and other staff. In V. Gordon, W. Habley, T. Grites, and Associates (Eds.), Academic advising: A comprehensive handbook (pp. 267-278). San Francisco, CA: Jossey-Bass.

Settle, J. S. (2011). Variables that encourage students to persist in community colleges. Community College Journal of Research and Practice, 35, 281-300.

Shaffer, L. S. (1998). Maximizing human capital by developing multicultural competence. NACADA Journal, 18(2), 21-27.

Shavelson, R. J. (1996). Statistical reasoning for the behavioral sciences ( $\left.3^{\text {rd }} \mathrm{ed}.\right)$. Boston, MA: Allyn \& Bacon.

Shultz, E. L., Colton, G. M., \& Colton, C. (2001). The Adventor program: Advisement and mentoring for students of color in higher education. Journal of Humanistic Counseling, Education \& Development, 40, 208-218.

Spady, W. G. (1970). Dropouts from higher education: An interdisciplinary review and synthesis. Interchange, 1(1), 64-85.

Stevens, J. (2009). Applied multivariate statistics for the social sciences $\left(5^{\text {th }}\right.$ ed.). New York: Routledge.

Sue, D. W., Bernier, J. E., Durran, A., Feinberg, L., Perderson, P., Smith, E. J., \& Vasquez-Nuttall, E. (1982). Cross-cultural counseling competencies. The Counseling Psychologist, 10(2), 45-52.

Tan, D. L. (1995). Perceived importance of role models and its relationship with minority student satisfaction and academic performance. NACADA Journal, 15(1), 48-51. 
Tinto, V. (1975). Dropout from higher education: A theoretical synthesis of recent research. Review of Educational Research, 45, 89-125.

Tinto, V. (1987). Leaving college: Rethinking the causes and cures of student attrition. Chicago, IL: University of Chicago Press.

Tinto, V. (1993). Leaving college: Rethinking the causes and cures of student attrition (2nd ed.). Chicago, IL: University of Chicago Press.

U.S. Department of Agriculture. (2013). Report on the definition of rural. Retrieved from http://www.rurdev.usda.gov/Reports/RDRuralDefinitionReportFeb2013.pdf

U.S. Department of Education, College completion tool kit, Washington, D.C., 2011.

U.S. Department of Education, National Center for Education Statistics. (2013). Time to completion, sex, control of institution, and cohort entry year [Table 376]. Retrieved from http://nces.ed.gov/pubsearch.

Van Gennep, A. (1960). The rites of passage. Chicago, IL: University of Chicago Press. Winston, R. B., \& Sandor, J. A. (1984). Developmental academic advising: What do students want? NACADA Journal, 4(1), 5-13. 


\section{APPENDIX A}

\section{National Academic Advising Association THE STATEMENT OF CORE VALUES OF ACADEMIC ADVISING}

\section{INTRODUCTION}

The National Academic Advising Association (NACADA) is comprised of professional and faculty advisors, administrators, students, and others with a primary interest in the practice of academic advising. With diverse backgrounds, perspectives, and experiences, NACADA members advise in a variety of settings and work to promote quality academic advising within their institutions.

NACADA recognizes and celebrates the contributions of professional, faculty, paraprofessional, and peer advisors to the advising profession. NACADA acknowledge $s$ the complex nature of higher education institutions and the role academic advising plays within them, the wide variety of settings and responsibilities of academic advisors, and advisors' diverse backgrounds and experiences. NACADA provides a Statement of Core Values to affirm the importance of advising within the academy and acknowledge the impact that advising interaction s can have on individuals, [sic] institutions and society.

The Statement of Core Values consists of three parts: 1) Introduction, 2) Declaration, and 3) Exposition, a descriptive section expanding on each of the Core Values. While each part stands alone, the document's richness and fullness of meaning lies in its totality.

The Statement of Core Values provides a framework to guide professional practice and reminds advisors of their responsibilities to students, colleagues, institutions, society, and themselves. Those charged with advising responsibilities are expected to reflect the values of the advising profession in their daily interactions at their institutions.

The Statement of Core Values does not attempt to dictate the manner in or process through which academic advising takes place, nor does it advocate one particular advising philosophy or model over another. Instead, these Core Values are the reference points advisors use to consider their individual philosophies, strengths, and opportunities for professional growth. Furthermore, the Core Values do not carry equal weight.

Advisors will find some Core Values more applicable or valuable to their situations than others. Advisors should consider each Core Value with regard to their own values and those of their institutions.

Advising constituents, and especially students, deserve dependable, accurate, timely, respectful, and honest responses. Through this Statement of Core Values, NACADA communicates the expectations that others should hold for advisors in their advising roles. Advisors' responsibilities to their many constituents form the foundation upon which the Core Values rest. 
The Statement of Core Values provides the guidance academic advisors seek from the National Academic Advising Association. The Statement is reviewed periodically to ensure its alignment with current professional practices and philosophies. The National Academic Advising Association encourages institutions to adopt the Statement of Core Values and support the work of those who provide academic advising.

Revised 2005 Copyright (C) 2005 by the National Academic Advising Association (NACADA) 


\section{National Academic Advising Association THE STATEMENT OF CORE VALUES OF ACADEMIC ADVISING}

\section{DECLARATION}

\section{1) Advisors are responsible to the individuals they advise.}

Academic advisors work to strengthen the importance, dignity, potential, and unique nature of each individual within the academic setting. Advisors' work is guided by their beliefs that students:

- have diverse backgrounds that can include different ethnic, racial, domestic, and international communities; sexual orientations; ages; gender and gender identities; physical, emotional, and psychological abilities; political, religious, and educational beliefs

- hold their own beliefs and opinions

- responsible for their own behaviors and the outcomes of those behaviors

- can be successful based upon their individual goals and efforts

- have a desire to learn

- have learning needs that vary based upon individual skills, goals, responsibilities, and experiences

- use a variety of techniques and technologies to navigate their world.

In support of these beliefs, the cooperative efforts of all who advise include, but are not limited to, providing accurate and timely information, communicating in useful and efficient ways, maintaining regular office hours, and offering varied contact modes.

Advising, as part of the educational process, involves helping students develop a realistic self-perception and successfully transition to the postsecondary institution. Advisors encourage, respect, and assist students in establishing their goals and objectives.

Advisors seek to gain the trust of their students and strive to honor students' expectations of academic advising and its importance in their lives.

\section{2) Advisors are responsible for involving others, when appropriate, in the advising process.}

Effective advising requires a holistic approach. At many institutions, a network of people and resources is available to students. Advisors serve as mediators and facilitators who effectively use their specialized knowledge and experience for student benefit. Advisors recognize their limitations and make referrals to qualified persons when appropriate. To connect academic advising to students' lives, advisors actively seek resources and inform students of specialists who can further assess student needs and provide access to 
appropriate programs and services. Advisors help students integrate information so they can make well-informed academic decisions.

\section{3) Advisors are responsible to their institutions.}

Advisors nurture collegial relationships. They uphold the specific policies, procedures, and values of their departments and institutions. Advisors maintain clear lines of communication with those not directly involved in the advising process but who have responsibility and authority for decisions regarding academic advising at the institution. Advisors recognize their individual roles in the success of their institutions.

\section{4) Advisors are responsible to higher education.}

Academic advisors honor academic freedom. They realize that academic advising is not limited to any one theoretical perspective and that practice is informed by a variety of theories from the fields of social sciences, the humanities, and education. They are free to base their work with students on the most relevant theories and on optimal models for the delivery of academic advising programs. Advisors advocate for student educational achievement to the highest attainable standard, support student goals, and uphold the educational mission of the institution.

\section{5) Advisors are responsible to their educational community.}

Academic advisors interpret their institution's mission as well as its goals and values. They convey institutional information and characteristics of student success to the local, state, regional, national, and global communities that support the student body. Advisors are sensitive to the values and mores of the surrounding community. They are familiar with community programs and services that may provide students with additional educational opportunities and resources. Advisors may become models for students by participating in community activities.

\section{6) Advisors are responsible for their professional practices and for themselves personally.}

Advisors participate in professional development opportunities, establish appropriate relationships and boundaries with advisees, and create environments that promote physical, emotional, and spiritual health. Advisors maintain a healthy balance in their lives and articulate personal and professional needs when appropriate. They consider continued professional growth and development to be the responsibility of both themselves and their institutions.

The Statement of Core Values provides the guidance academic advisors seek from the National Academic Advising Association. The Statement is reviewed periodically to ensure its alignment with current professional practices and philosophies. The National 
Academic Advising Association encourages institutions to adopt the Statement of Core Values and support the work of those who provide academic advising.

Revised 2005 Copyright (C) 2005 by the National Academic Advising Association (NACADA) 


\section{National Academic Advising Association THE STATEMENT OF CORE VALUES OF ACADEMIC ADVISING}

\section{EXPOSITION}

\section{Core Value 1: Advisors are responsible to the individuals they advise.}

- Academic advising is an integral part of the educational process and affects students in numerous ways. As advisors enhance student learning and development, advisees have the opportunity to become participants in and contributors to their own education. In one of the most important potential outcomes of this process, academic advising fosters individual potential.

- Regular student contact through in-person appointments, mail, telephone, E-mail, or other computer-mediated systems helps advisors gain meaningful insights into students' diverse academic, social, and personal experiences and needs. Advisors use these insights to assist students as they transition to new academic and social communities, develop sound academic and career goals, and ultimately, become successful learners.

- Advisors recognize and respect that students' diverse backgrounds are comprised of their ethnic and racial heritage, age, gender, sexual orientation, and religion, as well as their physical, learning, and psychological abilities. Advisors help students develop and reinforce realistic self-perceptions and help them use this information in mapping out their futures.

o Advisors introduce and assist students with their transitions to the academic world by helping them see value in the learning process, gain perspective on the college experience, become more responsible and accountable, set priorities and evaluate their progress, and uphold honesty with themselves and others about their successes and limitations.

o Advisors encourage self-reliance and support students as they strive to make informed and responsible decisions, set realistic goals, and develop lifelong learning and self-management skills.

o Advisors respect students' rights to their individual beliefs and opinions.

o Advisors guide and teach students to understand and apply classroom concepts to everyday life.

o Advisors help students establish realistic goals and objectives and encourage them to be responsible for their own progress and success.

o Advisors seek to understand and modify barriers to student progress, identify ineffective and inefficient policies and procedures, and work to affect change. When the needs of students and the institution are in conflict, advisors seek a resolution that is in the best interest of both parties. In cases where the student finds the resolution unsatisfactory, they inform students regarding appropriate grievance procedures. 
o Advisors recognize the changing nature of the college and university environment and diversity within the student body. They acknowledge the changing communication technologies used by students and the resulting new learning environments. They are sensitive to the responsibilities and pressures placed on students to balance course loads, financial and family issues, and interpersonal demands.

o Advisors are knowledgeable and sensitive regarding national, regional, local, and institutional policies and procedures, particularly those governing matters that address harassment, use of technology, personal relationships with students, privacy of student information, and equal opportunity.

o Advisors are encouraged to investigate all available avenues to help students explore academic opportunities.

o Advisors respect student confidentiality rights regarding personal information. Advisors practice with an understanding of the institution's interpretation of applicable laws such as the Federal Educational Rights and Privacy Act (FERPA).

o Advisors seek access to and use student information only when the information is relevant to the advising process. Advisors enter or change information on students' records only with appropriate institutional authorization to do so.

o Advisors document advising contacts adequately to meet institutional disclosure guidelines and aid in subsequent advising interactions.

\section{Core Value 2: Advisors are responsible for involving others, when appropriate, in the advising process.}

- Academic advisors must develop relationships with personnel critical to student success including those in such diverse areas as admissions, orientation, instruction, financial aid, housing, health services, athletics, academic departments, and the registrar's office. They also must establish relationships with those who can attend to specific physical and educational needs of students, such as personnel in disability services, tutoring, psychological counseling, international study, and career development. Advisors must also direct students, as needed, to experts who specialize in credit transfers, co-curricular programs, and graduation clearance.

- Because of the nature of academic advising, advisors often develop a broad understanding of an institution and a detailed understanding of student needs and the resources available to help students meet those needs. Based upon this understanding:

o advisors can have an interpretative role with students regarding their interactions with faculty, staff, administrators, and fellow students, and

o advisors can help the institution's administrators gain a greater understanding of students' needs.

- Students involved in the advising process (such as peer advisors or graduate assistants) must be adequately trained and supervised for adherence to the same 
policies and practices required of the professional and faculty advisors and other specially trained staff advising in the unit/institution.

\section{Core Value 3: Advisors are responsible to their institutions.}

- Advisors work in many types of higher education institutions and abide by the specific policies, procedures, and values of the department and institution in which they work. When circumstances interfere with students' learning and development, advisors advocate for change on the advisees' behalf with the institution's administration, faculty, and staff.

- Advisors keep those not directly involved in the advising process informed and aware of the importance of academic advising in students' lives. They articulate the need for administrative support of advising and related activities.

- Advisors increase their collective professional strength by constructively and respectfully sharing their advising philosophies and techniques with colleagues.

- Advisors respect the opinions of their colleagues; remain neutral when students make comments or express opinions about other faculty or staff; are nonjudgmental about academic programs; and do not impose their personal agendas on students.

- Advisors encourage the use of models for the optimal delivery of academic advising programs within their institutions.

- Advisors recognize their individual roles in the success of their institutions and accept and participate in institutional commitments that can include, but are not limited to, administrative and committee service, teaching, research, and writing.

\section{Core Value 4: Advisors are responsible to higher education in general.}

- Advisors accept that one goal of education is to introduce students to the world of ideas in an environment of academic freedom. Advisors demonstrate appreciation for academic freedom.

- Advisors base their work with students on the most relevant theoretical perspectives and practices drawn from the fields of social sciences, the humanities, and education.

- One goal of advising is to establish, between students and advisors, a partnership that will guide students through their academic programs. Advisors help students understand that learning can be used in day-to-day application through exploration, trial and error, challenge, and decision making.

- Advisors advocate for student educational achievement to the highest attainable standards and support student goals as they uphold the educational mission of the institution.

- Advisors advocate for the creation, enhancement, and strengthening of programs and services that recognize and meet student academic needs.

\section{Core Value 5: Advisors are responsible to their educational community.}


- Many institutions recognize the importance of integrating classroom learning with community experience, study abroad, and programs that bridge the gap between the academic and off-campus environments. Where such programs exist, advisors help students understand the relationship between the institution and local, regional, national, and international communities.

- Advisors advocate for students who desire to include study abroad or community service learning into their co-curricular college experience, and they make appropriate referrals to enable students to achieve these goals.

- Advisors understand the intricacies of transfer between institutions and make appropriate referrals to enable students to achieve their goals.

\section{Core Value 6: Advisors are responsible for their professional practices and for themselves personally.}

- Advisors use the Statement of Core Values to guide their professional actions.

- Advisors seek opportunities to grow professionally. They identify appropriate workshops, classes, literature, research publications, and groups, both inside and outside the institution, that can keep their interest high, hone professional skills, and advance expertise within specific areas of interest.

- Advisors seek cross cultural opportunities to interact with and learn more about ethnic communities, racial groups, religions, sexual preferences, genders, and age levels, as well as physical, learning, and psychological abilities and disabilities found among the general student population.

- Advisors recognize that research topics are embedded in academic advising practice and theory. Advisors engage in research and publication related to advising as well as in areas allied with their training and disciplinary backgrounds. Advisors' research agendas safeguard privacy and provide for the humane treatment of subjects.

- Advisors are alert to the demands surrounding their work with students and the necessity of taking care of themselves physically, emotionally, and spiritually to best respond to high level demands. They learn how to maintain listen and provide sensitive, timely responses that teach students to accept their responsibilities. Advisors establish and maintain appropriate boundaries, nurture others when necessary, and seek support for themselves both within and outside the institution.

The Statement of Core Values provides the guidance academic advisors seek from the National Academic Advising Association. The Statement is reviewed periodically to ensure its alignment with current professional practices and philosophies. The National Academic Advising Association encourages institutions to adopt the Statement of Core Values and support the work of those who provide academic advising.

Revised 2005 Copyright $\odot 2005$ by the National Academic Advising Association (NACADA) 


\section{APPENDIX B}

Table 1

Ten Central Components of the Advising Relationship

\begin{tabular}{|c|c|c|}
\hline Component & Prescriptive Approach & Developmental Approach \\
\hline Abilities & Focus on limitations & Focus on potentialities \\
\hline Motivation & Students are lazy, need prodding & Students are active, striving \\
\hline Rewards & Grades, credit, income & $\begin{array}{l}\text { Achievement, mastery, acceptance, status, } \\
\text { recognition, fulfillment }\end{array}$ \\
\hline Maturity & $\begin{array}{l}\text { Immature, irresponsible; must be closely } \\
\text { supervised and carefully checked }\end{array}$ & $\begin{array}{l}\text { Growing, maturing, responsible, capable of } \\
\text { self-direction }\end{array}$ \\
\hline Initiative & $\begin{array}{l}\text { Advisor takes initiative in fulfilling } \\
\text { requirements; rest up to student }\end{array}$ & Either or both may take initiative \\
\hline Control & By advisor & Negotiated \\
\hline Responsibility & By advisor to advise; by student to act & Negotiated \\
\hline Learner output & Primarily in student & Shared \\
\hline Evaluation & By advisor to student & Collaborative \\
\hline Relationship & Based on status, strategies, games, low trust & $\begin{array}{l}\text { Based on nature of task, competencies, } \\
\text { situation, high trust }\end{array}$ \\
\hline
\end{tabular}

Note. Adapted from Crookston, B. (1972), p. 14. 
Table 2

Skills, Knowledge, and Attitudes Required for Advising Students

Dimension

1. Exploration of life goals
Skills, Knowledge, and Attitude Required
(a) Knowledge of student characteristics
(c) Knowledge of psychology and sociology
(d) Skills in counseling techniques
(e) Appreciation of individual differences
(f) Belief in worth and dignity of all
(g) Belief that all have potential

2. Exploration of vocational goals (all under number 1 plus the following):
(a) Knowledge of vocational fields
(b) Skill in interpretation of tests
(c) Understanding of changing nature of work in society
(d) Acceptance of all fields of work as worthy and dignified

3. Program choice

(a) Knowledge of programs available in college

(b) Knowledge of programs (special entrance requirements, fees, time commitments)

(c) Knowledge of university requirements for transfer programs

(d) Knowledge of how others have performed in the program

(e) Knowledge of follow-up success of those who have completed the program

4. Course choice (a) Knowledge of courses available

(b) Knowledge of any special information regarding courses (prerequisites, offered only in certain times, transferability; does the course meet graduation requirements? [What is the appropriate sequence for the university?])

(c) Rules and regulations of the college regarding probation and suspension, limit on course load (academic and work limitations)

(d) Knowledge of honors courses or remedial courses

(e) Knowledge of instructors and their teaching styles

(f) Knowledge of student's ability through test scores, high school record 
Table 2 Continued.

Skills, Knowledge, and Attitudes Required for Advising Students

Dimension

5. Scheduling courses

Note. Adapted from O’Banion, T. (1972), p. 64.
Skills, Knowledge, and Attitude Required

(g) Knowledge of course content

(a) Knowledge of schedule

(b) Knowledge of the systems of scheduling and changing the schedule

(c) Knowledge of work and commuting requirements 
Table 3

Characteristics of a Multiculturally Competent Student Affairs Practitioner

\begin{tabular}{|c|c|c|}
\hline Multicultural Awareness & Multicultural Knowledge & Multicultural Skills \\
\hline $\begin{array}{l}\text { A belief that differences are } \\
\text { valuable and that learning } \\
\text { about others who are } \\
\text { culturally different is } \\
\text { necessary and rewarding. }\end{array}$ & $\begin{array}{l}\text { Knowledge of diverse } \\
\text { cultures and oppressed } \\
\text { groups (i.e., history, } \\
\text { traditions, values, customs, } \\
\text { resources, issues). }\end{array}$ & $\begin{array}{l}\text { Ability to identify and openly } \\
\text { discuss cultural differences } \\
\text { and issues. }\end{array}$ \\
\hline $\begin{array}{l}\text { A willingness to take risks and } \\
\text { see them as necessary and } \\
\text { important for personal and } \\
\text { professional growth. }\end{array}$ & $\begin{array}{l}\text { Information about how } \\
\text { change occurs for individual } \\
\text { values and behaviors. }\end{array}$ & $\begin{array}{l}\text { Ability to assess the impact } \\
\text { of cultural differences on } \\
\text { communication and } \\
\text { effectively communicate } \\
\text { across those differences. }\end{array}$ \\
\hline $\begin{array}{l}\text { A personal commitment to } \\
\text { justice, social change, and } \\
\text { combating depression. }\end{array}$ & $\begin{array}{l}\text { Knowledge about the ways } \\
\text { that cultural differences } \\
\text { affect verbal and nonverbal } \\
\text { communication. }\end{array}$ & $\begin{array}{l}\text { Capability to empathize and } \\
\text { genuinely connect with } \\
\text { individuals who are culturally } \\
\text { different from themselves. }\end{array}$ \\
\hline $\begin{array}{l}\text { A belief in the value and } \\
\text { significance of their own } \\
\text { cultural heritage and world } \\
\text { view as a starting place for } \\
\text { understanding others who are } \\
\text { culturally different from them. }\end{array}$ & $\begin{array}{l}\text { Knowledge about how } \\
\text { gender, class, race and } \\
\text { ethnicity, language, } \\
\text { nationality, sexual } \\
\text { orientation, age, religion or } \\
\text { spirituality, disability, and } \\
\text { ability affect individuals in } \\
\text { their experiences. }\end{array}$ & $\begin{array}{l}\text { Ability to incorporate new } \\
\text { learning and prior learning in } \\
\text { new situations. }\end{array}$ \\
\hline $\begin{array}{l}\text { A willingness to self-examine, } \\
\text { and when necessary, challenge } \\
\text { and change, their own values, } \\
\text { world view, assumptions, and } \\
\text { biases. }\end{array}$ & $\begin{array}{l}\text { Information about culturally } \\
\text { appropriate resources and } \\
\text { how to make referrals. }\end{array}$ & $\begin{array}{l}\text { Ability to gain the trust and } \\
\text { respect of individuals who } \\
\text { are culturally different from } \\
\text { themselves. }\end{array}$ \\
\hline $\begin{array}{l}\text { An openness to change and } \\
\text { belief that change is necessary } \\
\text { and positive. }\end{array}$ & $\begin{array}{l}\text { Information about the nature } \\
\text { of institutional oppression } \\
\text { and power. }\end{array}$ & $\begin{array}{l}\text { Capability to accurately } \\
\text { assess their own multicultural } \\
\text { skills, comfort level, growth, } \\
\text { and development. }\end{array}$ \\
\hline $\begin{array}{l}\text { An acceptance of other world } \\
\text { views and perspectives and a } \\
\text { willingness to acknowledge } \\
\text { that they, as individuals, do } \\
\text { not have all the answers. }\end{array}$ & $\begin{array}{l}\text { Knowledge about identity } \\
\text { development models and the } \\
\text { acculturation process for } \\
\text { members of oppressed groups } \\
\text { and its impact on individuals, } \\
\text { groups, intergroup relations, } \\
\text { and society. }\end{array}$ & $\begin{array}{l}\text { Ability to differentiate } \\
\text { between individual } \\
\text { differences, cultural } \\
\text { differences, and universal } \\
\text { similarities. }\end{array}$ \\
\hline
\end{tabular}

(Continued) 
Table 3 Continued.

\begin{tabular}{|l|l|l|}
\hline \multicolumn{1}{|c|}{ Multicultural Awareness } & Multicultural Knowledge & \multicolumn{1}{c|}{ Multicultural Skills } \\
\hline $\begin{array}{l}\text { A belief that cultural } \\
\text { differences do not have to } \\
\text { interfere with effective } \\
\text { communication or meaningful } \\
\text { relationships. }\end{array}$ & $\begin{array}{l}\text { Knowledge about within- } \\
\text { group differences and } \\
\text { understanding of multiple } \\
\text { identities and multiple } \\
\text { oppressions. }\end{array}$ & $\begin{array}{l}\text { Ability to challenge and } \\
\text { support individuals and } \\
\text { systems around oppression } \\
\text { issues in a manner that } \\
\text { optimizes multicultural } \\
\text { interventions. }\end{array}$ \\
\hline $\begin{array}{l}\text { Awareness of their own } \\
\text { cultural heritage and how it } \\
\text { affects their world view, } \\
\text { values, and assumptions. }\end{array}$ & $\begin{array}{l}\text { Information and } \\
\text { understanding of internalized } \\
\text { oppression and its impact on } \\
\text { identity and self-esteem. }\end{array}$ & $\begin{array}{l}\text { Ability to make individual, } \\
\text { group, and institutional } \\
\text { multicultural interventions. }\end{array}$ \\
\hline $\begin{array}{l}\text { Awareness of their own } \\
\text { behavior and its impact on } \\
\text { others. }\end{array}$ & $\begin{array}{l}\text { Knowledge about } \\
\text { institutional barriers which } \\
\text { limit access to and success in } \\
\text { higher education for } \\
\text { members of oppressed } \\
\text { groups. }\end{array}$ & $\begin{array}{l}\text { Ability to use cultural } \\
\text { knowledge and sensitivity to } \\
\text { make more culturally } \\
\text { sensitive and appropriate } \\
\text { interventions. }\end{array}$ \\
\hline $\begin{array}{l}\text { Awareness of the interpersonal } \\
\text { process which occurs within a } \\
\text { multicultural dyad. }\end{array}$ & $\begin{array}{l}\text { Knowledge about systems } \\
\text { theories and how systems } \\
\text { change. }\end{array}$ & \\
\hline
\end{tabular}

Source: Adapted from Pope and Reynolds, (1997, p. 271). 
Table 4

Key Categories and Search Terms for ERIC Database

\begin{tabular}{cccc}
\hline $\begin{array}{c}\text { Academic } \\
\text { Advising }\end{array}$ & Skills & Student & Satisfaction \\
\hline Advis* & Characteristics & Postsecondary & Perception \\
Academic & Effect* & Satisfaction \\
counsel* $^{\text {Techniques }}$ & Behaviors & Attitude \\
& Interpersonal & Preference \\
& competence & Relationship \\
& & satisfaction \\
& & Persistence \\
& & Graduation \\
& & Retention
\end{tabular}

Note. All terms are connected by OR within category, and AND across categories

${ }^{\text {a}}$ Yield: 279 records 
Table 5

Key Categories and Search Terms for PsychINFO Database

\begin{tabular}{cccc}
\hline Academic Advising & Skills & Student & Satisfaction \\
\hline Educational & Ability & College students & Satisfaction \\
counseling & Communication skills & & Student attitudes \\
& Professional & College \\
& competence & & academic \\
& Counselor attitudes & & achievement \\
& Counselor & Evaluation \\
& characteristics & & \\
\hline
\end{tabular}

Note. All terms are connected by OR within category, and AND across categories

${ }^{\mathrm{a}}$ Yield: 122 records 
Table 6

Individual Study Characteristics and Mean Effect Sizes for Satisfaction with Advising

\begin{tabular}{clcccccc}
\hline \multicolumn{1}{c}{ Study } & Independent Variable & $\begin{array}{c}\text { Publication } \\
\text { Status }\end{array}$ & Country & $N$ & $r$ & $\bar{z}$ & $95 \%$ CI \\
\hline Mottarella, et al. (2004) & $\begin{array}{l}\text { Comprehension of } \\
\text { degree requirements }\end{array}$ & Published & USA & 1671 & .294 & .304 & $.256, .353$ \\
Mottarella, et al. (2004) & $\begin{array}{l}\text { Interpersonal } \\
\text { communication }\end{array}$ & Published & USA & 1171 & .316 & .328 & $.271, .386$ \\
Mottarella, et al. (2004) & $\begin{array}{l}\text { Advising } \\
\text { techniques/approaches }\end{array}$ & Published & USA & 779 & .352 & .368 & $.297, .438$ \\
\hline
\end{tabular}

Note. $r=$ correlation coefficient; $\bar{z}=$ weighted average effect size for Fisher's $z$. 
Figure 4. Study Selection Flow Chart

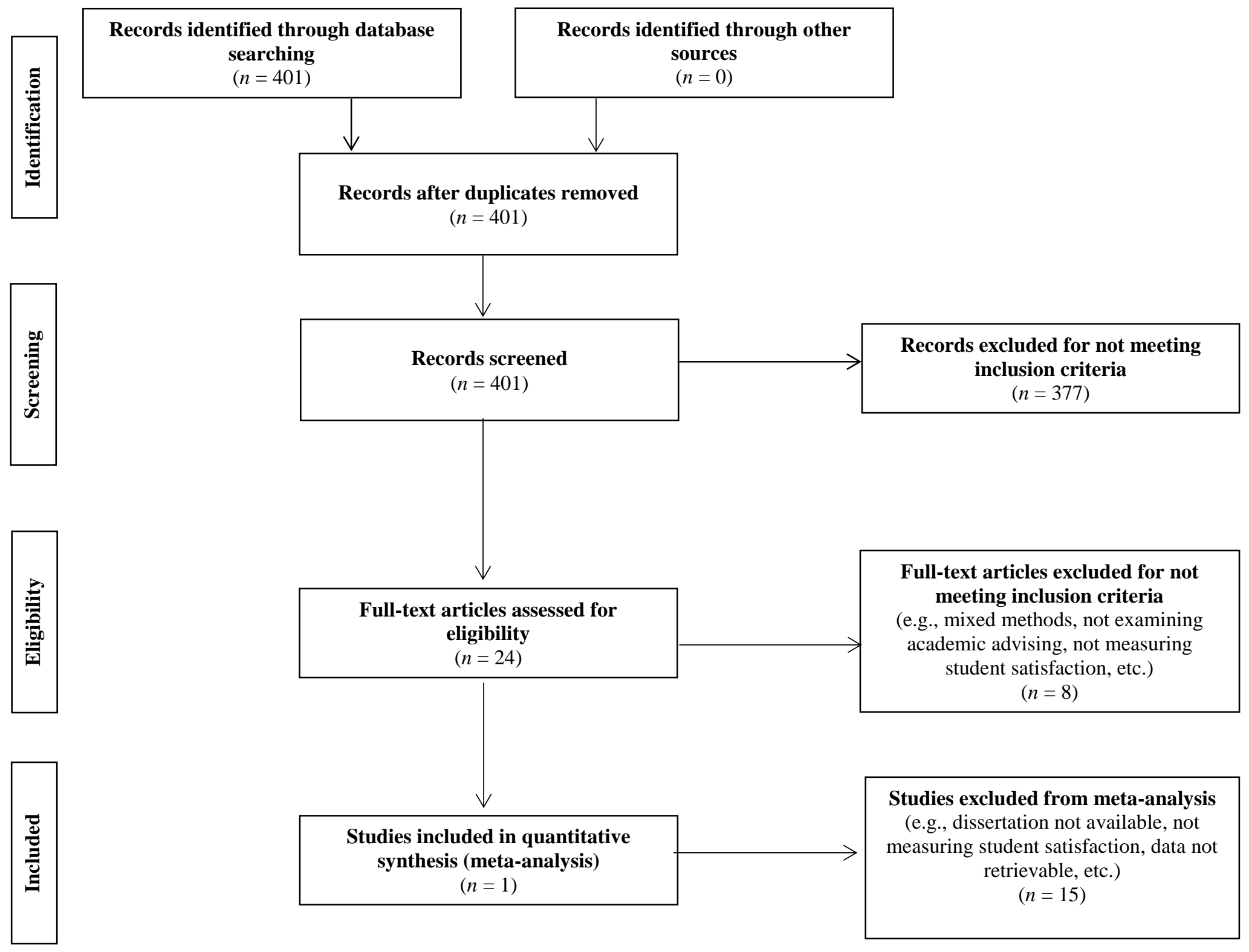




\begin{abstract}
APPENDIX C
Answering the Call: An Examination of Multicultural Competence Among Academic Advising Professionals

Recruitment/Reminder Email
\end{abstract}

Greetings Professional,

The purpose of this email is to request your assistance with my dissertation research study designed to better understand diversity and multiculturalism among academic advising professionals. This research will contribute to the scholarship regarding multicultural competence among academic advising professionals at the University of Louisville so that we, as practitioners, are in a better position to serve students and by extension, enhance learning.

To participate, please cut and paste the link below into your web browser and complete the short survey by Thursday, July 3.

\title{
https://louisvilleeducation.az1.qualtrics.com/SE/?SID=SV_5BwlZa315MemEDP
}

I am hopeful that you will agree to participate in this unique and exciting research opportunity. Please do not hesitate to contact me if you have questions or concerns (t0duma02@exchange.louisville.edu).

Sincerely,

Tia Dumas, Ph.D. Candidate

Counseling and Personnel Services (College Student Personnel)

University of Louisville 


\section{Demographic Questions}

Please respond to the following set of questions. You will notice many of the questions have multiple options. For those questions, please select the option(s) you feel are applicable to you and please check the "Not listed" option if you feel the options provided do not adequately represent your identity or identities.

1. For how many years have you been a professional (including graduate school) in academic advising or student affairs? (please enter numeric digits in years)

2. What is the highest degree or level of schooling your parent(s) or legal guardian(s) completed?

- High School Diploma or Equivalent

- Technical, trade, or vocational training or certification

- Associate's degree

- Bachelor's degree

- Master's degree

- Doctor's degree (e.g., Ph.D., Ed.D.)

- Professional degree (e.g., J.D., M.D., D.D.S.)

- Not listed

3. What is the highest degree or level of schooling you have completed?

- High School Diploma or Equivalent

- Technical, trade, or vocational training or certification

- Associate's degree

- Bachelor's degree

- Master's degree

- Doctor's degree (e.g., Ph.D., Ed.D.)

- Professional degree (e.g., J.D., M.D., D.D.S.)

- Not listed

4. Have you lived outside of the United States?

- Yes

- No

5. Have you traveled outside of the United States?

- Yes

- No

6. What is your age? (please enter in numeric digits) 
7. What is your race/ethnicity?

- American Indian or Alaska Native

- Asian

- Native Hawaiian or Pacific Islander

- Black or African American

- Hispanic or Latino/a

- Two or More Races

- White

- Not listed

- I prefer not to answer

8. Do you identify as a person with a disability?

- Yes

- No

- I prefer not to answer

9. What was your sex assigned at birth?

- Female

- Intersex

- Male

- Not listed

- I prefer not to answer

10. How do you identify your current gender identity? (check one only)

- Male

- Female

- Non-Binary (neither female nor male)

- Not listed

- I prefer not to answer

11. How do you identify your sexual orientation? (check one only)

- Lesbian

- Gay

- Bisexual

- Queer

- Questioning

- Straight

- Not listed 
- I prefer not to answer

12. What is your religious affiliation? (check one only)

- Atheist

- Agnostic

- Buddhist

- Christian

- Hindu

- Jewish

- Muslim

- Sikh

- None

- Not listed

- I prefer not to answer

13. What is your political affiliation? (check one only)

- Democrat

- Independent

- Republican

- Third Party

- No party

- Not listed

- I prefer not to answer

14. What is your annual household income? (check one only)

- Less than $\$ 20,000$

- $\$ 20,000$ - $\$ 39,999$

- $\$ 40,000-\$ 59,999$

- $\$ 60,000-\$ 79,999$

- $\$ 80,000-\$ 99,999$

- $\$ 100,000$ and above

- Not listed

- I prefer not to answer

15. In relation to your racial/ethnic identity, how would you describe the racial/ethnic composition of the population at your place of work over the last 3 years?

- Majority of the population is racially/ethnically similar to you

- Majority of the population is racially/ethnically dissimilar to you

- Not able to determine 
16. In relation to your racial/ethnic identity, how would you describe the racial/ethnic composition of your client base at your place of work over the last 3 years?

- Majority of the population is racially/ethnically similar to you

- Majority of the population is racially/ethnically dissimilar to you

- Not able to determine

17. What kinds of interactions have you had with individuals who are racially/ethnically dissimilar from you over the last 3 years?

- Dining/sharing meals

- Having discussions about racial/ethnic issues outside of work

- Sharing personal feelings/problems

- Meetings/appointments at work

- Attending events sponsored by other racial/ethnic groups

- Socializing/partying

- Having intellectual discussions outside of work

- Not listed

- Please describe the kinds of interactions you have had with individuals who are racially/ethnically dissimilar from you over the last three years if not listed.

18. On average, over the last 3 years, how often do you have these kinds of interactions with individuals who are racially/ethnically dissimilar from you?

- Once

- Daily

- Weekly

- Monthly

- Semi-annually

- Annually

19. How would you describe your desire to work with individuals who identify as a person from an underrepresented group in postsecondary education (i.e., firstgeneration college students, minority racial or ethnic groups, from families with low incomes, and/or from nontraditional ages and backgrounds)?

- No desire

- Weak desire

- Neutral desire

- Strong desire

- Very strong desire 
20. How would you describe your desire to work with individuals who identify as a person from a socially marginalized group (i.e., lesbian, gay, bisexual, queer, or questioning community, and/or religious minorities)?

- No desire

- Weak desire

- Neutral desire

- Strong desire

- Very strong desire

21. How would peers in your social circles describe your ability to be inclusive and sensitive to others from underrepresented and/or socially marginalized groups (as previously defined)?

22. How would your colleagues describe your ability to be inclusive and sensitive to others from underrepresented and/or socially marginalized groups (as previously defined)?

23. Overall, how would you describe the quality of the multicultural coursework and/or training you have participated in over the last 3 years?

24. What multicultural coursework and/or training have you participated in?

- Diversity workshop (e.g., conference session, in-service, lunch-and-learn, etc.)

- Webinar (e.g., a live event presented over the internet)

- Literature (e.g., journal articles, books, film, etc.)

- Academic courses

- AES/Master Advisor Certification training

- Internship or practicum with special populations (e.g., students with disabilities, adult learners, student-athletes, etc.)

- No training

- Not listed

- Please describe the kinds of multicultural coursework and/or training you have participated in over the last 3 years if it is not listed.

25. On average, over the last 3 years, how often did you participate in these kinds of trainings? (check one only)

- Once

- Daily

- Weekly

- Monthly

- Semi-annually 
- Annually

26. What obstacles or challenges do you encounter related to inclusion and cultural sensitivity with others over the last 3 years?

27. What additional thoughts or comments do you have about inclusion and cultural sensitivity, or about this survey?

(***Must request permission to use the MCSA-P2 Scale from the authors***) 


\section{APPENDIX D}

Table 10

Pearson Correlations for the Variables Included in the Regression Analysis

\begin{tabular}{lccccccccc}
\hline \multicolumn{1}{c}{ Variable } & 1 & 2 & 3 & 4 & 5 & 6 & 7 & 8 & 9 \\
\hline 1. MCSA-P2 Score & 1.000 & $.256^{*}$ & .005 & .049 & .108 & -.160 & $-.324^{*}$ & .034 & .121 \\
2. Race/Ethnicity & $.256^{*}$ & 1.000 & .035 & .177 & .069 & $-.199 *$ & -.052 & .152 & -.033 \\
3. Engagement & .005 & .035 & 1.000 & -.026 & -.161 & .030 & $.215^{*}$ & -.016 & .017 \\
4. Parent Degree & .049 & .177 & -.026 & 1.000 & .161 & .006 & -.145 & .056 & .141 \\
5. Professional Years & .108 & .069 & -.161 & .161 & 1.000 & -.185 & $.230^{*}$ & -.063 & $-.196^{*}$ \\
6. Participant Degree & -.160 & $-.199^{*}$ & .030 & .006 & -.185 & 1.000 & -.006 & .058 & .105 \\
7. MCC Training & $-.324^{*}$ & -.052 & $.215^{*}$ & -.145 & $.230^{*}$ & -.006 & 1.000 & -.128 & $-.303^{*}$ \\
8. Gender Identity & .034 & .152 & -.016 & .056 & -.063 & .058 & -.128 & 1.000 & .038 \\
9. Sexual Orientation & .121 & -.033 & .017 & .141 & $-.196^{*}$ & .105 & $-.303^{*}$ & .038 & 1.000 \\
\hline *Significant at the p<.05. & & & & & & & & &
\end{tabular}

*Significant at the $\mathrm{p}<.05$. 


\section{CURRICULUM VITAE}

\section{TIA N. DUMAS}

Department of Educational \& Counseling

Psychology, Counseling, and College Student

Personnel (ECPY)

University of Louisville

1905 South $1^{\text {st }}$ Street

Louisville, KY 40292

tia.dumas@louisville.edu
4018 Ballard Woods Drive Smithfield, KY 40068

502-225-9654 (hm)

541-912-4301 (cell)

\section{EDUCATION}

University of Louisville, Louisville, KY

Doctor of Philosophy in Counseling \& Personnel Services

2014

Advisor: Dr. Amy Hirschy, Ph.D.

University of Oregon

Master of Arts in Interdisciplinary Studies

University of Oregon

Bachelor of Arts in English Literature

\section{RESEARCH EXPERIENCE}

Postdoctoral Research Associate,

\section{University of Louisville}

Drs. Gaetane Jean-Marie and Jason Osborne

Present

Center for Educational Research, Policy, and Evaluation (CERPE)

Graduate Research Assistant,

$7 / 2013-6 / 2014$

Dr. Melissa Evans-Andris

Collaborative Approach to Relationships with a District School to Clinical Rigor for Effective Advancement of Teacher Education at Westport Middle School (CARDS to CREATE @ WMS:

A Clinical Model for Middle Grades Teacher Preparation)

- Evaluator, assist project lead evaluator with field research, including field observation, indepth interviewing, and document analysis

Graduate Research Assistant,

Drs. Amy Hirschy, John Braxton, and Maureen Wilson

Norms of Academic Advising Professionals

- Conduct initial literature search and literature review of professional norms in academic advising

- Assist with the development of an IRB protocol and securing IRB approval for later study

- Assist with survey design development 


\section{Graduate Research Assistant,}

$1 / 2010-9 / 2011$

Drs. M. Shelley Thomas and Fashaad Crawford

College of Education \& Human Development Perception of Diversity Study

- Assisted study team leaders with Institutional Review Board protocol

- Identified campus climate survey instruments and examined psychometric properties

\section{ACADEMIC EMPLOYMENT}

\section{University of Louisville}

Graduate Teaching Assistant, College Student Personnel

$1 / 2013-12 / 2013$

Department of Educational \& Counseling Psychology, Counseling, and College Student

Personnel

- Co-teach graduate courses in college student development theory and college student subcultures

- Advise and mentor master's and doctoral level students

- Assist with syllabus design and grading assignments

- Assist program faculty with recruitment of and outreach to prospective student affairs professionals

Instructor, Freshmen Seminar

$8 / 2008-10 / 2012$

Department of Health \& Sport Sciences

- Taught undergraduate courses in university and departmental procedures, culture, and skills for success for incoming first-year students

- Provided advising and mentoring to undergraduate students

\section{TEACHING}

- Teaching Assistant,

$1 / 2013-12 / 2013$

ECPY 661 Theories of College Student Development

University of Louisville Faculty: Amy Hirschy, Ph.D.

- Teaching Assistant,

$1 / 2013-12 / 2013$

ECPY 664 College Student Subcultures

University of Louisville Faculty: Michael Cuyjet, Ed.D.

- Instructor,

$2008-2013$

HSS 181 Freshmen Seminar in Health and Sport Sciences

University of Louisville

\section{PUBLICATIONS}

(Johnson, T. N.) (2011). Voices from the field: What makes a good supervisor [Monograph]? Academic Advising Administration: Essential Knowledge and Skills for the $21^{\text {st }}$ Century, 22, 165-167.

Dumas, T. N. (2004). Women of color in sport: A literature review of the history and current status of women of color in intercollegiate coaching and athletic administration.

Kinesiology Abstracts 18(1). 


\section{SELECTED PRESENTATIONS}

(Johnson, T.), Larson, A. E., \& Thomas, M. S. (2014, March). Investing in Character and Quality: Using Teacher Candidates' Reported Perceived Habits to Direct Culturally Sustaining Pedagogy. Presentation at the American Association of Colleges for Teacher Education Annual Meeting.

NACADA Diversity Committee (2012, October). Becoming a global community in academic advising: helping NACADA diversify its membership. Panel presentation at the National Academic Advising Association Conference.

(Johnson, T.), \& Stout, J. A. (2011, October). Check yo'self: you can foster inclusion, equity, and excellence in your advising unit. Presentation at the National Academic Advising Association Conference.

Burton, A., Burton, N., (Johnson, T.), \& Owen, D. (2010, November). Institute for cultural competence and courageous practice: Working together for inclusion, equity, and excellence. Presentation at the National Association for Multicultural Education Conference.

Armstrong, K. A. S., (Johnson, T.), \& Stout, J. A. (2009). Hitting the multicultural advising trifecta: Students, structure, and strategies. Presentation at the Kentucky Academic Advising Association Inaugural Conference.

Armstrong, K. A. S., (Johnson, T.), \& Stout, J. A. (2009). Hitting the multicultural advising trifecta: Students, structure, and strategies. Presentation at the National Academic Advising Association Conference.

(Johnson, T.), \& Cox, K. (2008, December). Reality Check: Advising students out of a major. Presentation at the University of Louisville Annual Conference Sharing Event.

Pentecost, M. W., Hampton, B., Bergman, M., \& (Johnson, T.) (2008, October). Coaching employees to reach new heights. Presentation at the National Academic Advising Association Conference.

\section{INVITED PRESENTATIONS \& TRAININGS}

\section{University of Louisville}

Armstrong, K. A. S., \& (Johnson, T.) (2012, October). Knowing me, knowing you: a strategic guide to creating a culturally responsive advising program. Invited pre-conference workshop at the National Academic Advising Association Conference.

(Johnson, T.) (2012, May). Check yo 'self: you can foster inclusion, equity \& excellence. Invited presentation for College of Arts and Sciences peer advisors, University of Louisville, Louisville, KY.

(Johnson, T.) (2011, November). Check yo 'self: you can foster inclusion, equity \& excellence. Invited presentation for Faculty "Lunch and Learn," University of Louisville, Louisville, KY. 
(Johnson, T.) (2011, March). Inclusion, equity, and excellence in academic advising. Invited presentation for Resources for Academic Achievement (REACH), University of Louisville, Louisville, KY.

(Johnson, T.) (2011, February). Inclusion, equity, and excellence in academic advising. Invited presentation for Principles and Practices of Academic Advising graduate course, University of Louisville, Louisville, KY.

Pentecost, M. W., \& (Johnson, T.) (2010, October). Surviving the financial crunch: Alternative funding. Invited pre-conference workshop at the National Academic Advising Association Conference.

Pentecost, M. W., \& (Johnson, T.) (2009, October). Developing grant proposals for advising projects. Invited pre-conference workshop at the National Academic Advising Association Conference.

Pentecost, M. W., \& (Johnson, T.) (2008, October). Developing grant proposals for advising projects. Invited pre-conference workshop at the National Academic Advising Association Conference.

\section{University of Oregon}

McMahon, T., Mitchell, W., \& Dumas, T. N. (2006, February). How to lead with a vision. Invited presentation for Student's Leadership Symposium, University of Oregon, Eugene, OR.

Dumas, T. N. (2006, January). Women of color in leadership positions in intercollegiate athletics. Invited presentation for Office of Academic Advising, University of Oregon, Eugene, OR.

McMahon, T., Mitchell, W., \& Dumas, T. N. (2005, February). How to lead with a vision. Invited presentation for Student's Leadership Symposium, University of Oregon, Eugene, OR.

\section{ADMINISTRATIVE EMPLOYMENT}

Academic Counselor, Senior, Education Advising \& Student Services

$1 / 2008-7 / 2013$

University of Louisville, College of Education \& Human Development

Academic Advisor, Office of Multicultural Academic Support

$9 / 2004-12 / 2007$

University of Oregon, Office of Inclusion, Equity and Diversity

Graduate Assistant, Student-Athlete Academic Services

$9 / 2001-6 / 2003$

University of Oregon, Athletics

\section{PROFESSIONAL SERVICE}

American Association of Colleges for Teacher Education

- Advocate, 2013 \& 2014 Day on the Hill (AACTE)

2013 - present

National Academic Advising Association

- Member, National Academic Advising Association (NACADA),

$2011-2013$ 
Diversity Committee

- Evaluation and Registration Volunteer, National Academic Advising 2012 Association (NACADA)

- Proposal Reviewer, National Academic Advising Association 2012 (NACADA)

- Proposal Reviewer, National Academic Advising Association and Kentucky Academic Advising Association (KACADA) Mid-South Regional Conference

Kentucky Academic Advising Association

- Proposal Reviewer, National Academic Advising Association and Kentucky Academic Advising Association

Mid-South Regional Conference

\section{SELECTED UNIVERSITY SERVICE AND LEADERSHIP}

\section{University of Louisville}

- Student Representative, College of Education \& Human Development Diversity Committee

- Member, Diversity Ad-Hoc Committee, Office of Academic Affairs and Unit Effectiveness, College of Education \& Human Development

- Member, Search Committee for Assistant Director for Undergraduate Advising, College of Education \& Human Development

2012 - present

Member, Search Committee for Early Childhood Teacher Aid, College of Education \& Human Development

- Staff Representative, College of Education \& Human Development Diversity Committee

- Member, Search Committee for Education Advising Center, Academic Coordinator, Senior

- Member, Advising Syllabus Implementation Committee

\section{University of Oregon}

- Advocate, Bias Response Team

- Cluster Facilitator, LeaderShape Institute, University of Oregon

- Member, Diversity Building Scholarship Awards Committee

$2005-2007$

- Member, Intercultural Leadership Institute Committee

2006

- Member, Queer Students of Color Reception Planning Team

2006

- Member, Adviser/Counselor Search Committee,

2006 Office of Academic Advising

- Reader, Hesser and Pincetich Scholarship Committee, Disability Services

- Presenter, Oregon Football Recruiting Brunch

- Member, Excellence Awards Committee

- Member, Assistant/Associate Vice Provost for Institutional Equity and Diversity Subcommittee

- Member, NCAA Steering Committee

$2005-2006$

- Member, NCAA Subcommittee on Academic Integrity

$2005-2006$ 
- Member, McNair Scholarship Interview Committee

$2005-2006$

- Member, Family Programs and Commencement Search Committee

$2005-2006$

- Member, Staff Psychologist Search Committee, Counseling and Testing Center

- Panelist, Sexual Wellness Advocacy Team (SWAT)

$2005-2006$

2005

\section{PROFESSIONAL DEVELOPMENT}

- Collaborative Institutional Training Initiative (CITI),

$2013-2014$

University of Louisville

- Participant, PLAN Workshops, School of Interdisciplinary

\& Graduate Studies (SIGS), University of Louisville

- Master Advisor Certification Training, University of Louisville

$2013-2014$

- Participant, Race Relations Conference, Louisville, KY

2011

- Participant, I2A Critical Thinking Workshop, University of Louisville

2010

- Safe Zone Training, Office for Lesbian, Gay, Bisexual

2010

\& Transgender Services, University of Louisville

2010

- Coordinator, Friends \& Confabulations Culturally Responsive Advising Training

- Attendee, Undergraduate Advising Practice- Sponsored Trainings and In-Services, University of Louisville

- Attendee, NACADA-Sponsored Webinars

- Advisor Education Seminar (AES II), University of Louisville

- Cultural Competence and Courageous Practice Institute, University of Louisville and Jefferson County Public Schools

- Advisor Education Seminar (AES I), University of Louisville

2009 - present

2008 - present

2008 - present

2009

2009

2008

\section{PROFESSIONAL MEMBERSHIPS}

- Member, American Educational Research Association (AERA)

- Member, Association for the Study of Higher Education (ASHE)

- Member, American Association of Colleges for Teacher Education (AACTE)

- Member, National Association for Multicultural Education (NAME)

- Member, National Association for Multicultural Education (NAME), Louisville Chapter, Louisville, KY

- Member, National Academic Advising Association (NACADA)

- Member, Kentucky Academic Advising Association (KACADA)

2014 - present

2013 - present

2012 - present

$2010-2011$

$2010-2011$

2008 - present

$2009-2010$

\section{PROFESSIONAL HONORS}

- PLAN Workshop Participation Certificate, University of Louisville 2014

- Faculty Mentor Award, Committee on Academic Performance 2014 of the University of Louisville Athletic Association, University of Louisville

- Master Advisor Award, University of Louisville

- Faculty Mentor Award, Committee on Academic Performance of the University of Louisville Athletic Association, 
University of Louisville

- NACADA Outstanding Certificate of Merit, Academic 2011 Advising-Primary Role

- NACADA Mid-South Region 3, Outstanding Primary Advisor 2011

- Faculty Mentor Award, Committee on Academic Performance 2011 of the University of Louisville Athletic Association, University of Louisville

- Staff Senate Resolution of Thanks, University of Louisville

2011

- Provost's Award for Exemplary Advising, University of Louisville

$2010-2011$

- Nominee, Provost's Award for Exemplary Advising, University of Louisville

$2009-2010$

- Women of Color Conference Recognition Award, University of Oregon 2006

- Black Student Union Recognition Award, University of Oregon 2005

\section{ACADEMIC HONORS}

- Holmes Scholar, American Association of Colleges for Teacher

2012 - present Education (AACTE), University of Louisville

- Scholar Athlete, University of Oregon Athletics, University of Oregon

$1998-2000$ 